\title{
WestVirginiaUniversity
}

THE RESEARCH REPOSITORY @ WVU

Graduate Theses, Dissertations, and Problem Reports

2003

\section{The Life Cycle of a Coal Town: Widen, West Virginia, 1911-1963}

Amanda J. Griffith

West Virginia University

Follow this and additional works at: https://researchrepository.wvu.edu/etd

Part of the Labor History Commons, and the United States History Commons

\section{Recommended Citation}

Griffith, Amanda J., "The Life Cycle of a Coal Town: Widen, West Virginia, 1911-1963" (2003). Graduate Theses, Dissertations, and Problem Reports. 7990.

https://researchrepository.wvu.edu/etd/7990

This Thesis is protected by copyright and/or related rights. It has been brought to you by the The Research Repository @ WVU with permission from the rights-holder(s). You are free to use this Thesis in any way that is permitted by the copyright and related rights legislation that applies to your use. For other uses you must obtain permission from the rights-holder(s) directly, unless additional rights are indicated by a Creative Commons license in the record and/ or on the work itself. This Thesis has been accepted for inclusion in WVU Graduate Theses, Dissertations, and Problem Reports collection by an authorized administrator of The Research Repository @ WVU. For more information, please contact researchrepository@mail.wvu.edu. 
The Life Cycle of a Coal Town:

Widen, West Virginia, 1911-1963

\author{
Amanda J. Griffith \\ Thesis submitted to the \\ Eberly College of Arts and Sciences at \\ West Virginia University \\ in partial fulfillment of the requirements \\ for the degree of
}
Master of Arts
in
History

\begin{abstract}
Ronald L. Lewis, Ph.D., Chair
Kenneth Fones-Wolf, Ph.D.

Michael Workman, Ph.D.
\end{abstract}

\title{
Department of History
}

\author{
Morgantown, West Virginia \\ 2003
}

Keywords: Coal Mining and Organized Labor, Strikes and Lockouts,

Labor Disputes, Clay County, West Virginia

Copyright 2003 Amanda J. Griffith 


\section{Abstract \\ The Life Cycle of a Coal Town: \\ Widen, West Virginia, 1911-1963}

\section{Amanda J. Griffith}

The Elk River Coal and Lumber Company and its president, Joseph Gardner Bradley, built the town of Widen located in Clay County, West Virginia. As coal production proved successful, the coal town rapidly grew and by 1950 , Widen offered amenities such as a Y.M.C.A., theater, soda fountain, schools, and churches for the diverse composition of miners to enjoy. In 1952, a fifteen-month strike marked the climax of the history of Widen. The struggle between the local union, known as the League of Widen Miners, and the United Mine Workers of America, resulted in the destruction of company and private property, physical assaults, a general reduction of law and order in town, and eventually, the death of a non-striking miner. Although successfully fending off the UMWA, Bradley sold the mine in 1958 and it eventually closed in 1963. The town has been slowly deteriorating ever since and hardly resembles the booming coal town of yesteryear. 


\section{Table of Contents}

\section{Page}

Abstract

ii

List of Tables

iv

Abbreviations

iv

Introduction

1

Chapter 1 - A Coal Town Is Born: The Beginnings of Widen

5

Chapter 2 - The Miner's Freedom

Chapter 3 - The Formative Years: The Reign of "King Bradley"

29

Chapter 4 - The Rebellious Years: Widen at War

Chapter 5 - Old Age Sets In: The Decline of Widen

Conclusion

84

Bibliography

87

Appendix - Going Back Home to Widen

92 


\section{List of Tables}

Figure 1 - Elk River Coal and Lumber Company Operational Statistics

Figure 2 - Ethnicity of ELRICO Workers 1910-1930

\section{Abbreviations}

ELRICO Elk River Coal and Lumber Association

NIRA National Industrial Recovery Act

NLRA National Labor Relations Act

NLRB National Labor Relations Board

UMWA United Mine Workers of America

WCALO Widen Citizens' Association for Law and Order 


\section{Introduction}

As the coal industry grew in the mid eighteenth century, small coal towns began springing up along the landscape of Appalachia. Early towns were wild, lawless settlements that came and went with the discovery and depletion of a supply of coal. Still, because of the seemingly limitless supply of some coal deposits, many of these remote settlements evolved into towns, eventually supporting large populations. The birth of a coal town usually followed the rail lines. Operators opened drift mouth mines along the railroad as they made their way into the heart of Appalachia. The death of these towns came almost as sudden as birth. After the supply of coal was depleted, coal operators would pack up and leave the town and its residents behind with no means of employment. The result has been poverty and deprivation in many of these dead coal towns of Appalachia.

Located between high, rugged mountains, most coal towns began with a mine opening and a tipple. Soon after establishment of a mine, a coal operator would begin to build homes to house the rising number of miners entering the settlement looking for work. These early settlements usually featured a large number of male occupants and did not offer a sense of community or safety in which a miner would chose to raise a family. Once a mine proved its worth and an operator believed he would mine coal for a substantial period of time, he would begin to develop the settlement around the mine. Soon, coal operators began the process of "cleaning up" their rugged coal settlements and more homes would be built as well as stores and entertainment facilities.

The newly developed coal towns entered maturity at the height of the coal mine's production. Operators employed many miners whose families filled the homes and streets of the coal towns. In the rapid maturation of the coal town, operators developed paternalistic intentions and began to assume the role of the benevolent provider of the town and its miners. In line with the Old South model of the paternalistic slave plantation, the company usually built the superintendents' and operators' homes on a hill overlooking the town, establishing their dominance over the working class miners. 
Because of their ensuing dominance, most coal operators became synonymous with their coal towns. J.G. Bradley and his town of Widen are no different. ${ }^{1}$

Joseph Gardner Bradley came from a long line of politicians, from a Secretary of War to United States Senators. His father died when he was seven years old, and his mother moved home to live with her family, the McCormicks of Pennsylvania. After completing his education and training to become a lawyer and politician, he chose to venture to West Virginia to run his uncle and grandfather's burgeoning business, the Elk River Coal and Lumber Company. Bradley came to Clay County in 1904 as a right-ofway agent for the Buffalo Creek and Gauley Railroad and soon moved up in the ranks of the company. He became President of the railroad, General Manager of Elk River Coal and Lumber Company, and eventually President of the company. Over his fifty years connected with the company, Bradley sought the role of provider and benevolent dictator of the town. As general manager of the company, Bradley began his campaign to make the town a respectable establishment, requesting materials to build homes for the miners and their families.

Throughout his tenure as president of the Elk River Coal and Lumber Company, Bradley lived in Clay County. His home was in Dundon, just across the Elk River from the town of Clay. Because of his upbringing in New England, he was considered by some Clay County residents to be an aristocrat. But, Bradley has been quoted as saying he never considered himself a Bostonian, implying he felt more connected to his Clay County home. Still, his actions speak louder than words and what would seem his true feelings towards his Clay County home have been summed up in an article for

\section{Goldenseal:}

[Bradley] did not choose to live in Widen, his town, and he built his home far away from everyone else's. No one came to his home except for business purposes. He seemed to avoid Widen as much as possible, in fact he put the mine superintendent in charge of the town. He often went to Florida or New York for two or three weeks at a time. This was part of his philosophy. He probably did not think it would be a good idea to become too close to his people. He had three different types of clothes for the

\footnotetext{
${ }^{1}$ W.P. Tams, The Smokeless Coal Fields of West Virginia: A Brief History (Morgantown: West Virginia University Libraries, 1963), 5.
} 
three towns [of the Elk River Coal and Lumber Company]. He wore his best clothes in Widen, his next best in Swandale, and patchy ones in Dundon. At least he wanted people to feel he was one of them. It is difficult to meet someone who really knew this man. ${ }^{2}$

Although Bradley resided in Dundon, it is difficult to say that he was a Clay County resident. While in the county, he remained detached from his people, the miners of Widen. Once the mines closed, he moved back to Massachusetts, where he lived until his death. If Bradley truly considered himself a resident of Clay County, he would have chosen to live the remainder of his life in Dundon and not moved back to New England. This fact illustrates Bradley's role as paternalistic operator. He wanted to put forth the image that he was the same as the miners in order for them to remain loyal to him. If he had lived in Massachusetts while operating a mine in West Virginia, the men would not have felt as connected to him and would not have been as adamant in keeping the United Mine Workers of America out of Widen. As a result of his pretense of nativity, Bradley successfully operated his large non-union company for fifty years with only one major industrial conflict.

The strike of 1952-53 marked the climax in the story of Widen. Because striking miners would not be rehired to work in Widen, many were forced to move out of Widen to find work. This first wave of migration out of Widen would not be the last. After Bradley sold his mine, and the subsequent closing of the mine five years later by the Clinchfield Coal Company, Widen began to decline. The company rapidly dismantled the mining equipment, leaving the town without a means of support and caused more miners to move away in search of work. Those that stayed resided in a town that little resembled the Widen of the past. At the beginning of the twenty-first century, Widen can be officially declared a dead town. The only remnants of the once booming coal town are several company houses still standing in rows.

The story of Widen is not unusual in its rise and fall, in fact, it is merely a representative of numerous coal towns throughout Appalachia that have seen the boom

\footnotetext{
2 Betty Cantrell, Grace Phillips, and Helen Reed, "Widen: The Town J.G. Bradley Built," Goldenseal 3, no. 1 (January-March 1977): 2.
} 
and bust cycle as a result of the coal industry. What sets Widen apart from other coal towns is its significant labor history. The fact that it operated for nearly fifty years without any major industrial conflict regarding union representation makes the operation unique. The strike wave of the 1920s in West Virginia did not reach the small, isolated town of Widen and it would take another thirty years for miners in Widen to want United Mine Workers of America representation. 


\section{Chapter 1 A Coal Town is Born: The Beginning of Widen}

Formed on March 29, 1858 from sections of Nicholas and Braxton Counties, Clay County is located in the central part of West Virginia. The county is named after Henry Clay and is comprised of around 350 square miles. The terrain is hilly and rocky, with mostly inadequate topsoil for farming, but there are some good farming areas located in the lower elevations of the county. Clay County has long been a remote section of the state, isolated from major industrial development. Early settlers were sparse, as there were no roads into the central wilderness that could transport numerous inhabitants into the county. The Elk River runs southwesterly through the county for forty-five miles, providing the only means of transportation into the area during its early years. Because of the lack of transportation networks, the population of the county dwindled for most of the early history, with only twenty-eight families living in Clay County by 1839 . Deer, bear, turkey, panthers, and wolves roamed the landscape, providing food and clothing for these early settlers. Early county meetings convened at the Two Run meeting house, but after the creation of the state of West Virginia in 1863, the county built a courthouse in the town of Henry, better known as Clay Town. ${ }^{1}$

One of the major developmental turning points in Clay County history was the coming of the railroad. On December 15, 1895, the Charleston, Clendenin, and Sutton Railroad completed its tracks to the Clay County courthouse. Shortly after the completion to Clay, the railroad continued up the Elk River, reached Ivydale, and eventually made its way to Elkins in Randolph County. The Baltimore and Ohio Railroad acquired this early railroad line for its Charleston branch after World War I. With the inroads created by the branching of the railroad, industrial and residential development in the county took off. New manufactured products, mail, newspapers, and visitors began entering the county, connecting the once isolated wilderness with the world outside the county lines, while also opening the area for mineral resource development. Oil, natural gas, and timber all featured prevalent in the county industrial

\footnotetext{
${ }^{1}$ Clay County Historical Society, History of Clay County I (Clay: Clay County History Book Committee, 1989), 1-16. Clay Town was eventually referred to as Clay.
} 
expansion, but coal became the major resource development in the northeastern corner of Clay County. ${ }^{2}$

The coal town of Widen is located on a 93,000-acre plot of land in Clay County, West Virginia. President Abraham Lincoln granted the land to his Secretary of War, Simon D. Cameron. Cameron's son, James, inherited the property and as a partner in the Elk River Coal and Lumber Association began building a coal and timber empire in the late nineteenth century. The association began by purchasing additional land in the region from Henry Murphy in 1896, as well as land from a bankrupt mining company. Joseph Gardner Bradley, grandson of James Cameron, explained how his family came to the Clay County region in a speech in 1958: "My Grandfather got interested in our property out here in 1869 ...land that belonged to the West Virginia Iron Mining and Manufacturing Company, which had gone into bankruptcy and was split up into lots and sold."

The association bought land from the defunct West Virginia Iron Mining and Manufacturing Company, gave Murphy a down payment for the land, and made arrangements to pay the balance owed him with the sale of the timber off of the property. The Elk River Coal and Lumber Association was comprised of several stockholders including James McCormick Cameron (the son of James Donald Cameron), Vance McCormick, a Mr. Wetherills, a Mr. Bayard, Isaac Tomb, a Mr. Thompson, Henry Brockerhoff, and Thomas Swann, with each share representing approximately 10,000 acres. The company began timbering the land in Clay County, and reaping large benefits. Four of the stockholders, Thompson, Wetherills, Tomb, and Swann took their profits, paid off their debt, and asked to partition off their portion of the property. Swann eventually remained a stockholder after the Elk River Coal and Lumber Association gave him the job of running a timber business on the property in the new town of Swandale. ${ }^{4}$

When timbering of the area began, the Elk River Coal and Lumber Association found several "squatters" on their land. Bradley later explained there were farmers living

\footnotetext{
${ }^{2}$ Clay County Historical Society, History of Clay County II (Clay: Clay County History Book Committee, 1989), 17

3 "Widen: An Appalachian Empire," Hickory and Lady Slippers: Life and Legend of Clay County People IV (Clay: Clay County High School, 1979), 6.

${ }^{4}$ Clay County Historical Society, History of Clay County I, 44.
} 
on the plots of land divided as a result of the bankruptcy of the West Virginia Iron Mining and Manufacturing Company, and his company granted these farmers the right to live on the land. Bradley believed the farmers "had lived there all their lives so we thought [they] ought to keep it." company land, but only after first attempting to remove them. The association hired a lawyer and surveyors to check any disputed tracts of land, bring suit to those on company land, and evict those who refused to leave. The lawyers began a policy of visiting the squatters a few days before the set trial for their respective disputed land rights, offering a compromise. The lawyers would suggest that the association keep the mineral and timber rights, while the squatters could continue to live on the property, farming the timbercleared land. Many chose to sign over their full claim to the land and ended up with only the surface rights, yet a few chose to dispute the conglomerate and won claim to their land in court. ${ }^{6}$ In the end, the company did grant farmers the right to live on the land they had lived on for generations only after they signed over the mineral and timber rights to the Elk River Coal and Lumber Association.

In addition to the timber business, the Elk River Coal and Lumber Association discovered coal deposits around the town of Dundon and began mining there around 1897. In 1898, Captain Baird Haberstadt, a mine prospector for the Elk River Coal and Lumber Association, discovered a finer grade of coal nineteen miles from Dundon, and the association quickly planned to open a new mine in that area as well. ${ }^{7}$

By the early twentieth century, several of the men on the board of Elk River Coal and Lumber Association were deceased, leaving their heirs a trust administered by a bank in Philadelphia. The bank received five percent of the amount of money it disbursed among the stockholders' heirs. Upon incorporation of the newly established Elk River Coal and Lumber Company, the Philadelphia bank placed several bank directors upon the board of the company, who were in charge of directing the investment side of the

\footnotetext{
5 "Widen: An Appalachian Empire," 6.

${ }^{6}$ Ibid, 44.

${ }^{7}$ Cantrell, et al, 2; Wild Wonderful Widen, (Widen: Institute of Cultural Affairs, 1980), 3.
} 
company, while a rising, young entrepreneur, J.G. Bradley took care of developing the business end of the company. ${ }^{8}$

Joseph Gardner Bradley was born in Newark, New Jersey on September 12, 1881. Bradley came from a long line of politicians and lawyers. He was the son of William Hornblower Bradley and Eliza McCormick Cameron Bradley. His paternal grandfather, Joseph P. Bradley was an Associate Justice of the United States Supreme Court and his great-grandfather, Joseph C. Hornblower was a Chief Justice of the New Jersey Supreme Court. His maternal great-grandfather was Simon Cameron, Secretary of War under President Lincoln. Cameron was also appointed Minister to Russia and served as a United States Senator from Pennsylvania. Bradley's maternal grandfather James Cameron, a stockholder of the Elk River Coal and Lumber Association, served as Secretary of War under President Grant and also served as a United States Senator from Pennsylvania. $^{9}$

Bradley attended Newark Academy and St. Mark's School before graduating from Harvard Law School in 1904. After choosing not to practice law, he proceeded to travel to Clay County representing the Elk River Coal and Lumber Association as a rightof-way agent for the Buffalo Creek \& Gauley Railroad (BC\&G). In 1905 he married Mable Warren, acquiring her family riches. Warren was the granddaughter of Thomas F. Bayard, a former Secretary of State, Ambassador to Great Britain, and United States Senator from Delaware. Using his cunning business skills and family riches, Bradley quickly moved up in the ranks of the newly established Elk River Coal and Lumber Company, becoming the Superintendent of the BC\&G then General Manager, Vice President, and eventually President of ELRICO. ${ }^{10}$

At the same time ELRICO began its business ventures in Clay County, major railroad companies were making inroads to central and southern West Virginia. The Chesapeake and Ohio Railroad built branch lines into the southern part of the state, the Norfolk and Western Railroad penetrated the Pocahontas coal field, and the Baltimore

\footnotetext{
${ }^{8}$ Clay County Historical Society, History of Clay County I, 45.

${ }^{9}$ Walter E. Clark, West Virginia Today (New Orleans: West Virginia Editors Association, 1941), 158.

${ }^{10}$ Cantrell, et al, 2-3; John W. Kirk, compiler, Progressive West Virginians (Wheeling: The Wheeling Intelligencer, 1923), 175; Clark, 158.
} 
and Ohio Railroad made inroads into the northern part of the state. With the expansion of the railroad into the depths of Appalachia, the coal industry began to develop at a rapid pace. Northern capitalists began invading the region and buying land and mineral rights with "the sole purpose... to make money for their stockholders." ${ }^{11}$ Land companies who owned the land on which the coal deposits were located would lease the land to coal operators who would mine the coal. In return, the coal operators paid the land companies a royalty on each ton of coal mined. A standard lease between a coal operator and a land company around 1900 featured similar stipulations. Typically, the lessee paid all the taxes on the land, a ten cent royalty per ton of coal mined to the land company, along with $\$ 7.50$ per acre minimum per year on the land being rented. The leaser also required the lessee to survey the land. In return, the land company granted the timber rights to the coal operator to use for timber supports in the coal mines and building materials for the coal town. ${ }^{12}$

As coal mines opened throughout Appalachia, towns began to grow up around each mine opening. The emergence of a coal town followed the same general guidelines. A coal operator would lease from a land company an area of land and the minerals under that land. The coal operator had sole authority over the operations of the mine, the miners, and the development of the coal town. Most of these operators did not make large profits, but the opportunity to succeed was readily available. Numerous small coal operations with dreams of making fortunes appeared in Southern West Virginia, but many found those fortunes hard to make. For example, in 1904, the cost of producing a ton of coal was eighty-five cents, but the selling price for a ton of coal was eighty cents. Therefore, operators actually lost money on every ton of coal they mined. ${ }^{13}$

By the beginning of the twentieth century, cities and industries were becoming more and more dependent upon coal. With the continuous need for this fuel, it became burdensome when these small coal companies, operating on a shoestring, would go under, leaving cities and companies without a constant supply of coal. Small operations

\footnotetext{
${ }^{11}$ David Alan Corbin, Life, Work, \& Rebellion in the Coal Fields: The Southern West Virginia Miner, 1880-1922 (Urbana: University of Illinois Press, 1981), 9.

12 Tams, 31.

${ }^{13} \mathrm{Ibid}, 25$. Operators soon found the difference and profits they needed could be made in the miners' rent for housing and the money miners spent on supplies at the company store.
} 
in rural Appalachia also found it difficult to obtain customers. Thus, it became imperative for the coal industry to develop a more reliable supply of coal and railroad companies answered the call. By establishing sales companies, railroads began to assume the role of the middleman between coal operators and customers, keeping the flow of coal steady in the economy. Although sales companies began as middlemen in the coal industry, they soon turned into a profit making business forcing coal operators to pay freight on the coal the railroad was hauling out of the rural area. Faced with monopolistic prices and oppressive tactics, a rural coal operator had no choice but to use railroads as a sales agents or he might have found it difficult to ship his coal anywhere for lack of cars made available by the railroad company. ${ }^{14}$

Looking to maximize profits, railroads began moving into rural areas trying to develop monopolies on the transportation networks for remote coal mines. Railroads not only made a profit on the freight transported out of the area, they also made money on rent paid by some coal companies. When constructing a rail line into an area, a railroad company would buy the right-of-way for the land on which the rail line laid. This rightof-way gave the company control over the coal under the land that the railroad ran upon. In order to mine the coal found below the railroad's tracks, a coal company would lease the land from the railroad, paying rent to extract the minerals. ${ }^{15}$

Unlike other coal companies in southern West Virginia that were forced to lease land from railroad companies, the Elk River Coal and Lumber Company owned the land its coal company mined, freeing it from paying royalties to a land company. By the time ELRICO established a new timber and mine operations in the northeast corner of Clay County, transportation of those resources out of the isolated area became the only major problem for the company. To alleviate the transportation problem, ELRICO began plans to build a railroad on its property in 1904. The Buffalo Creek and Gauley Railroad would eventually connect the four burgeoning towns supporting the company's lumber and coal businesses.

Dundon is the oldest of the four ELRICO towns and is located across the Elk River from the town of Clay. The headquarters of the Elk River Coal and Lumber

\footnotetext{
${ }^{14}$ Ibid, $25-28$.

${ }^{15}$ Ibid, 25-26.
} 
Company were located here along with railroad repair shops. The town had homes for the workers in the company office and railroad shops, though because of its close proximity, many ELRICO employees who worked in Dundon lived in the town of Clay. A school, company store, post office, and community building were also integral parts of the community of Dundon. ${ }^{16}$

Named after Elk River Coal and Lumber Company stockholder Captain Thomas Swann, Swandale was the lumber town of the company and is located on the lower part of the Buffalo Creek, eleven miles east of Dundon and nine miles west of Widen. A sawmill opened in the town in 1910 to process the lumber being cut by the Elk River Coal and Lumber Company. A lumberyard, homes for workers, a boarding house, a school, and an auditorium used for community activities, such as a theatre, were all situated in the town. Steam heat from the sawmill provided heat to the houses, school, and clubhouse. ${ }^{17}$

The Elk River Coal and Lumber Company's dairy farm was situated in the town of Cressmont. Located two miles west of Swandale, the dairy farm was comprised of a herd of cattle, a barn, and a bottling plant. The cattle from Cressmont provided the other three company town stores with fresh milk and meat. ${ }^{18}$

On April 1, 1904, the Buffalo Creek and Gauley Railroad was chartered to run from Dundon to Huttonsville, in Randolph County. By 1909, a crew of 70 to 80 men, under the leadership of L.G. Widen, built the railroad between Cressmont and Dundon, and began construction of the railroad to the new mine opening east of Dundon. In 1911, the eighteen-mile railroad reached the area where the town of Widen would eventually be

\footnotetext{
16 "Widen: An Appalachian Empire," 11.

${ }_{17}^{17}$ Clay County Historical Society, History of Clay County I, 40.

18 "Widen: An Appalachian Empire," 10.
} 
located. On July 14 of that year, the BC\&G Railroad hauled the first load of coal out of the new Rich Run mine. ${ }^{19}$

Shortly after the mine began production, postal authorities requested a name for the new town that was building up around the mine. Rich Run was the first suggestion because it was the name of the mine, but the postal department requested a one-word name. The workers on the railroad respected Mr. Widen and requested that the town be named after him. He rejected the offer at first, not wanting his name to be on a "wild coal mining town." He eventually agreed with the proviso that Bradley had to make the town respectable by the time he visited again or he would sue ELRICO for damages. ${ }^{20}$ Bradley soon set to work building a town that would honor Mr. Widen's name and wishes.

As the new mine proved successful, more and more men traveled to Widen for work. As a result, the once isolated area in the northeast corner of Clay County became a culturally diverse settlement, filled with new inhabitants all of different races and

${ }^{19}$ William E. Warden, Buffalo Creek \& Gauley (Highland Mills: Ed Crist, Inc., 1991), 3-4. During the extent of its lifetime, the Buffalo Creek and Gauley Railroad was the largest all steam railroad in North America and transported almost a million tons of coal a year from the mine at Widen. It generally hauled a train of fifty to sixty cars of coal a day from Widen to Dundon, where it connected with the Baltimore and Ohio Railroad's Charleston Branch. It is highly unlikely the railroad was ever planned to have such a far-reaching route to Huttonsville. Warden states that no evidence exists that this route would ever be realized, but he believes that Bradley, a rising "transportation magnate," would not admit to only achieving to build an 18-mile railroad. Yet, in 1904, Bradley had little influence in the operations of the company, as he merely served as a right-of-way agent for the railroad; Cantrell, et al, 2; Wild Wonderful Widen, 3. Warden's book lists the beginning of construction as beginning in 1904 and reaching Widen by 1905. Other sources have noted the construction of the BC\&G as beginning in 1909 and reaching Widen in 1911; West Virginia Department of Mines and Mining, Annual Report (Charleston: Department of Mines and Mining, 1923), 48-9. The Rich Run mine was part of the Kanawha \#5 seam and featured heights of up to six feet.

${ }^{20}$ Cantrell, et al, 2. L.G. Widen was born in Stockholm, Sweden in 1855 and came to America in 1882. Mr. Widen returned twenty years later and stated, "Mr. Bradley kept his word. He has really made a town out of it." One wonders what Mr. Widen would think of Widen if he were alive today; Crandall Shifflett, Coal Towns: Life, Work, and Culture in Company Towns of Southern Appalachia, 1880-1960 (Knoxville: University of Tennessee Press, 1991), 34; Clay County Historical Society, History of Clay County II, 82. One of the most common practices was to name the coal town after a company official. Fifty percent of coal towns were named after a pioneer operator, founder, or owner; Randall Gene Lawrence, "Appalachian Metamorphosis: Industrializing Society on the Central Appalachian Plateau, 1860-1913" (Ph.D. diss., Duke University, 1983), 165-237. Most people considered coal mining towns at the turn of the twentieth century as wild towns. Murders, rapes, drinking, gambling, and prostitution all took place on a regular basis in the early years of a developing coal mining town. The lawlessness and rambunctious nature of developing coal towns resulted in the paternalistic movement of coal operators to provide entertainment that would give miners other means of recreation than debauchery. Companies also resorted to guards that would patrol the company property, enforcing law and order. 
ethnicities. Faced with a rising population, Bradley began building a town around his mine that could support his rising workforce numbers. By the 1920s, the town had grown into a true coal community, hardly resembling the coal settlement of the early 1900s. With the development of the coal community came the ever-present control of the company. The freedom once experienced by the isolated settlers in early county history was replaced with J.G. Bradley's iron fist that completely ruled the town from mine to man. 


\section{Chapter 2 \\ The Miner's Freedom}

Work in the mines at Widen changed from the first ton mined in 1911 to the last ton mined in 1963. As the town evolved over generations, so did the life in the mines. To understand the culture of the miner and his community is to understand his life underground. The miners' experience in the mines in many ways determined the life they lived above ground. This chapter explores the culture of the miner as defined by his work underground.

The life and work of a miner has changed dramatically since the first miners went underground. The freedom experienced by first generation miners has vanished, replaced by an integrated mechanical production system. Machines have removed the laborintensive craft previously involved in mining, and altered the job to require technical and mechanical skills. Mechanization in the mines not only changed the working life of miner, it also had great influence on the social and community life of the miner. As machines replaced workers in the mines, displaced miners had no choice but to leave behind the familiar life they had known in coal communities, and search for employment elsewhere. By the 1950s, the culture of the miner had begun to decline, and by the turn of the twenty-first century, the culture is almost extinct.

A rapid growth of the coal industry began in the mid-nineteenth century, as coal became the powering fuel behind the development of the Industrial Revolution in the United States. Enterprising businessmen throughout the Appalachian region began to establish small coal mine operations and hoped to benefit from the burgeoning demand for the fossil fuel. Most of these small coal mines operated from day to day, and operators prayed not to go bankrupt before the end of the year. Besides relying on a fluctuating market, these small coal operators also depended upon the miner and his skill for the success of a mine operation.

Early miners extracted coal by the room and pillar technique. This system was simple and inexpensive, but very dangerous and wasteful. The miner would cut the seam of coal into corridors on either side of a "wall," and workrooms were opened off of the main corridor. A pillar was left in between each workroom to support the roof. Then, 
working from the back of the corridor, the miner would cut as much coal as he could from the surrounding walls. Homer Morris vividly described the layout of room and pillar mines, relating them to an expansive underground city. He likened the main entry of the mines to Main Street and side streets spurred off parallel to the main entry as the mine was developed. These side entrances also crossed with other entries, making a grid system of passageways underground.

Rooms about twenty-four feet wide are made at regular intervals at right angles off of these cross entries. The side walls of the rooms are known as pillars, and are left unmined in order to support the roof until the rooms are worked out. The height of the room is usually determined by the thickness of the coal seam, which varies from two to four feet. The rooms are usually, however, scarcely high enough for a man to stand erect.... The room is advanced a few feet each working day into the solid coal in the direction of the next cross entry. ${ }^{1}$

The process of mining helped establish the miner's freedom of work. Early mining was a skill, a craft acquired from years working with coal seams and learning the hazards of the mine. First, the miner undercut the seam. This process was accomplished while the miner lay on his side and used a pick to cut into the bottom of the coal seam. Once the undercutting was finished, he then prepared to blast the seam. The miner drilled holes into the seam using either a hand, or breast, auger about five feet long. $\mathrm{He}$ then filled the holes with powder and a fuse, and packed both in the hole with clay. The skill of blasting was a delicate process requiring the miner to determine how much powder would be needed to break the coal he just undercut without damaging the roof or face of his workspace, and hopefully making it easier to shoot his next load of coal.

Once the blast broke the coal, the miner then shoveled the coal into cars. The strenuous task of loading coal cars usually took half of the miner's work time. ${ }^{2}$

After the miner cleared the workroom of coal, he then began to cut into the pillar. The room and pillar process would eventually leave a large space of roof exposed, supported by timbers. The remaining pillar was soft and easy to mine, but removing too much coal from a supporting pillar would cause a roof fall. As the miner cut into the

\footnotetext{
${ }^{1}$ Homer Morris, Plight of the Bituminous Miner (Philadelphia: University of Pennsylvania Press, 1934), 64-5, 84.

${ }^{2}$ Ibid, 65-6.
} 
pillar the roof would eventually begin to "give," breaking from the weight above it. Miners learned to know when the roof was just "working" and when it was about to collapse. Once the roof collapsed, the pressure on the rest of the corridor was relieved. ${ }^{3}$

Coal companies paid a miner by the ton in the early days of coal mining. Therefore, the amount of work he put in each day determined his daily wage. This piece rate pay system also helped establish the miner's freedom in the mines. The ability to come and go as he pleased gave the miner much more freedom than industrial workers in factories that worked on strict schedules. Nevertheless, a miner usually worked a full day's work and only left the mines if he had no coal cars to load, if a shot misfired, or if a tool broke. Other reasons for a miner leaving work might be because he had "cleaned up" before closing time or that he had felt he earned enough that day. ${ }^{4}$

Although the type of pay system and the craft nature of mining helped establish the idea of freedom, the main factor in the development of the miner's freedom at work were the isolated working conditions he experienced. The miner was given a workspace to mine as he pleased, without the direct supervision of a foreman. The square mileage of a mine made it impossible for a foreman to constantly supervise a single miner all day. It was more common for a foreman to visit a miner only once a day, and that visit would most likely involve the miner airing his complaints about the lack of coal cars to load, instead of the foreman complaining about the lack of production by the miner. ${ }^{5}$ Miners saw the foreman more as a safety inspector than production enforcer. A miner thought of himself as a contract worker, therefore his workroom was his to do as he pleased. A miner used his own tools and powder to mine, therefore he believed the company had no right to enforce policies on him in his workspace. And the company gave the miner his freedom, unless his work threatened the overall production of coal or endangered the lives of the other coal miners in the mine. ${ }^{6}$

The coal industry expanded rapidly from 1880 to 1920 as a result of the industrial development in the United States. This rapid growth resulted in the opening of numerous

\footnotetext{
${ }^{3}$ Keith Dix, What's a Coal Miner to Do? The Mechanization of Coal Mining (Pittsburgh: University of Pittsburgh Press, 1988), 3-4.

${ }^{4}$ Carter Goodrich, The Miner's Freedom (New York: Arno Press, 1925), 41; Dix, 13.

${ }^{5}$ Goodrich, 15-19, 40-1.

${ }^{6}$ Ibid, 33-37.
} 
small mines throughout the industry, which also meant a large number of newly employed miners. The industry did experience a slight downturn in the first two decades of the 1900s, but World War I brought back a high demand for coal to fuel the fight for democracy around the world. In the immediate post-war years, however, the coal industry entered into a protracted decline. The production pace set during the rapid expansion of the industry began to exceed the demand for coal. Filled with too many mines and miners, the coal industry continued to overproduce, lessening coal's market price and causing widespread unemployment during the $1920 \mathrm{~s}^{7}$

In his book The Plight of the Bituminous Miner, Homer Morris attributes several reasons for the overproduction of the coal industry, but also states that the main underlying factors in overproduction were the desire for profits by coal companies and the lack of effective regulation over the industry. Significant reasons for overproduction were inroads on coal's markets by alternative fuels. The use of more efficient and cheaper fuels, such as oil, natural gas, and water power resulted in the decline of demand for coal. Technological advances in the burning of coal also reduced demand. ${ }^{8}$

Secondly, transportation networks stimulated overproduction. For example, railroads wanted more coal in order to maximize freight and profits. To secure a steady flow of coal, railroad companies established sales agencies, which effectively precluded price competition among the operators, but was denounced by both railroad officials and mine operators. The possibility of being the sole provider of coal to a sales agency spurred overproduction in coalfields as coal companies sought to prove their production capacities. Railroads also helped encourage production by opening previously unavailable, widespread markets to the coal operators on their line. ${ }^{9}$ Also, coal car shortages from 1916 to 1918 led the Interstate Commerce Commission to create a rule that determined coal car allotment by the production of the mines; the more a mine produced, the higher its quota for coal cars. Thus, mines overproduced to raise production numbers in order to secure a steady supply of coal cars. ${ }^{10}$

\footnotetext{
${ }^{7}$ Richard Mark Simon, "The Development of Underdevelopment: The Coal Industry and Its Effect on the West Virginia Economy, 1880-1930" (Ph.D. diss., University of Pittsburgh, 1978), 58.

${ }^{8}$ Morris, 8-13.

${ }^{9}$ Simon, 92-94.

${ }^{10}$ Morris, 3-4.
} 
The lack of a standard wage in the industry was a major factor to stimulate the opening of new mines, which further aggravated the problem of overproduction. The Jacksonville Agreement of 1924 officially set the standard for a higher union wages for miners, but having to pay higher wages, union companies were often underbid by nonunion companies from West Virginia and Kentucky. As early as the 1910s, many union operators began terminating their contracts to allow them to meet the low wage scale of non-union companies. The high wage scale established by the Jacksonville Agreement, only helped compound the rising number of union contracts being broken by coal companies. A series of mine wars occurred during the 1920s as the UMWA fought this anti-union movement. The result of the Jacksonville Agreement was a lack of regulation of the wage scale in the coal industry, leaving individual operators free to establish their own wage rates, regardless of union standards. The absence of a wage scale also hastened the advent of the industry in the southern coalfields. New mines opened in the South that only compounded the large number of competitors in a declining industry. ${ }^{11}$

Seasonal fluctuations in the coal industry also helped add to the overproduction of coal. Demand for coal greatly increased during the winter months and to meet this demand, coal companies either produced over capacity during the rest of the year or hired seasonal workers, which resulted in "unemployment, reduced wages, high production costs, and cutthroat competition to secure orders in a buyers market."12 These fluctuations in the industry caused sporadic and irregular work schedules. Many mines only worked two-thirds of a year even in the boom years between 1890 and $1930 .^{13}$

Summing the problem, Morris attributes overproduction to the general declining condition of the coal industry. Morris stated that the "failure of free competition and price to adjust mine capacity to demands of the market has caused the coal industry to be designated the worst functioning industry in the world." Besides the economic ailments, other problems specific to the industry plagued the coal industry. For example, mines

${ }^{11}$ Ibid, 13-14; Simon, 84-96. Initial investment costs were also lower in West Virginia than in other coal fields because most mines in West Virginia could be accessed by drift mine openings, not requiring the costs of constructing a shaft into the mines. Simon also attributes the influence of landowners in West Virginia as a major factor in over development of the state's coal production. Since landowners were paid a royalty on every ton produced, they urged high production to maximize their profits.

${ }^{12}$ Morris, 15.

${ }^{13}$ Simon, 58. 
depreciate more when not in use. Rotting timbers, water and gas accumulation, and roof falls went unreported when there were no miners underground. Therefore, even if coal companies sold coal at a loss it was still cheaper to keep producing coal in a declining market than stop production all together and risk creating a deteriorated mine. ${ }^{14}$

Richard Mark Simon also discusses the declining condition of the coal industry at the beginning of the twentieth century in his dissertation, "The Development of Underdevelopment." He attributes the problems of the industry to "destructive competition." According to Simon, the early twentieth century American economy was characterized by a "development of vertically integrated corporations due to the aggregate growth of the United States economy." Large corporations attempted to dominate and stabilize industries through controlled prices and low production costs. Smaller companies, unable to compete with these corporations, were eventually absorbed by a larger company or experienced total business failure. But, the coal industry did not take part in this consolidation movement because there was no force to control competition, prices, or production in that industry. ${ }^{15}$

Like Morris, Simon attributes the decline of the coal industry to the unique supply and demand forces in which it operated. Simon also argues that the development of nonunion fields in the industry, and the resultant overproduction, were major factors in the decline of the coal industry. However, Simon goes even further to examine the development of the combination movement, and its failure, for the persistence of destructive competition in the coal industry. As the merger wave between 1895 and 1905 swept the United States' economy, the coal industry, like every other industry, looked to business consolidations for help. In theory, larger companies could buy the best lands and most modern machinery while minimizing production costs. Therefore, large companies could lower their prices below small coal companies' prices and drive them out of business. Industry officials hoped this reduction in the number of operators would reduce the overproduction of coal. ${ }^{16}$

\footnotetext{
${ }^{14}$ Morris, 6 .

${ }^{15}$ Simon, 28-32.

${ }^{16}$ Ibid, 102-103
} 
Despite the efforts, the combination movement in the coal industry failed and Simon attributes four factors to this failure. First, more small firms entered the industry during the World War I boom, even though there were already too many producers of coal in the industry. A second factor was the internal growth of companies already established in the coal industry. Medium-sized coal companies could grow through mechanization, which reduced production costs and allowed them to compete with large companies. Third, intraindustry impacts on the coal industry, such as the lack of ability to eliminate competition, no effective barriers to entry, and the absence of product differentiation, patents, and resource control would not allow large companies to control the industry. Finally, Simon attributes interindustry factors, such as railroads and the steel industry for forcing competition among independent coal operators in order to prove high production numbers that would secure railroad transportation and steady markets, such as steel companies. Unable to enforce any effective control over price or production, coal companies turned to the only factor it could control effectively: labor. ${ }^{17}$

Efforts on the part of coal companies to reduce labor costs resulted in the impetus to mechanize the process of coal mining. Based on Frederick Taylor's model of scientific management, coal companies sought ways to make their mines more efficient. Scientific management looked for ways to break down production or manufacturing processes into simple tasks that individuals could perform separately, producing a single product faster than if an individual person manufactured the entire product alone. The influence of scientific management in the mines broke the craft of mining into four individual tasks: undercutting, drilling, blasting, and loading. Coal companies sought to efficiently perform each of these tasks and looked to machines to achieve their goals. ${ }^{18}$

The 1922 United States Coal Commission recommended a new program of mechanization and reorganization in the coal industry. The commission cited four areas of improvement for the industry: replacement of "irksome and solitary operations of hand loading;" more control of underground operations; higher efficiency for the individual

\footnotetext{
${ }^{17}$ Ibid, 104-143.

${ }^{18}$ Dix, 80-91.
} 
worker; and a standardization of equipment in the mines. ${ }^{19}$ Yet, decades before the commission's report, machinery had been developed that would make each task easier and simpler to perform, while making the mining operations more efficient and profitable. The first process to be mechanized was undercutting.

Undercutting machinery was introduced into American mining operations as early as the 1870s. The first undercutting machine incorporated a cutter-bar that scraped the coal to undercut the seam. The Lechrer cutter-bar device, later manufactured by the Jeffrey Manufacturing Company, was comprised of a revolving steel bar with small picking teeth mounted to it and powered by compressed air. The next introduction was the pick or punching machine. Compressed air also powered this machine, which was comprised of a piston with a steel bit attached to it that undercut the coal seam along the same manner as a miner with a pick would. ${ }^{20}$ Coal operators quickly incorporated the timesaving technology of undercutting machinery in the mines, and by 1900 a quarter of all coal was mechanically undercut. By 1920, undercutting machines cut 61 percent of the coal being mined, and a decade later, 81 percent of coal mined in the United States was mechanically undercut. ${ }^{21}$

Undercutting machinery helped increase the production of coal, but loading time was the main hindrance to higher production in the mines. In the early twentieth century, miners spent 55 to 65 percent of their time loading coal. ${ }^{22}$ This time consuming task significantly slowed the production of coal, and placed the pace of production in the laborers' hands, not management. ${ }^{23}$ Therefore, the push to develop a machine that would load coal became a priority in the coal industry. Early mining and loading machines were the McKinlay and Jeffrey-Morgan entry drivers. Both of these machines cut, broke, and loaded coal simultaneously. The machines would bore forward into the face of the coal seam and, as the coal was cut from the seam, push it onto a conveyor system that transported the coal to a car at the back of the machine. Another loading machine, the

\footnotetext{
${ }^{19}$ Ibid, 80; John L. Lewis, Miners' Fight for American Standards (Indianapolis: The Bell Publishing Company, 1925), 114-5.

${ }^{20}$ Dix, 28-32.

${ }^{21}$ Ibid, 4, 78; Simon, 161.

${ }^{22}$ Goodrich, 28.

${ }^{23}$ Dix, 81-2.
} 
Myers-Whaley shoveling machine, "scooped up the coal and threw it back on a conveyor which carried it back in to a car." Room conveyors, such as the pit car loader could be positioned directly over the shot down coal, allowing a miner to shovel the coal directly onto the conveyor that would transport the coal to a coal car. ${ }^{24}$ Although all of these machines helped quicken the pace of the mining process, no machine was more widely used in the coal industry than the Joy loading machine.

Two conveyors and mechanical gathering arms were the working apparatuses on Joy's loading machine. The first conveyor ran from the gathering arms to a storage hopper and the second conveyor ran from the hopper to a coal car. The machine provided "improved devices by which the coal is gathered from the floor of the mine onto the conveyor by which it is deposited in the pit cars. ${ }^{25}$ In the 1920s, Joy redesigned his machine to be a "self-loading shuttle car...for gathering coal from the floor at the face, transporting it out of chamber to gangway and loading it into mine cars." Joy's machines allowed coal production while switching a full coal car with an empty car, which was a remarkable step in timesaving techniques used in mining coal. Joy's innovations in mine machines made great inroads into mine operations and by 1954, the Joy loader loaded seventy percent of coal in mines. ${ }^{26}$

As a result of mechanization in the mines, specialization of work tasks reduced miner's duties to laying track for mine cars, timbering, separating slate from coal, shoveling coal left behind by the machines, or operating the mining and loading machines. Mining no longer was a labor-intensive craft, miners' duties changed to technical tasks required to run a machine or shovel coal. With the increasing specialization also came regimentation in the mines. Because miners did not produce coal as individuals, they were no longer paid by the ton, and so operators began paying the miners at an hourly rate. Hourly pay also meant that miners must work a specific amount of time during the day. Gone were the days of the miner's freedom that allowed him to leave when he felt like it. The mines became a disciplined working space that

\footnotetext{
${ }^{24}$ Ibid, 34-46.

${ }^{25}$ Ibid, 68-9.

${ }^{26}$ Ibid, 73-6; Curtis Seltzer, Fire in the Hole: Miner and Managers in the American Coal Industry (Lexington: University of Kentucky Press, 1985), 13.
} 
could only function when the miners followed management's control. Still, by this time, most mines were thoroughly unionized, which did not allow operators to have complete control over miners' working environment.

The new machines made life in the mines more dangerous. The large machines hardly conformed to the small spaces in the mines and frequently caused roof falls, caveins, bodily harm to miners, and explosions. It was not uncommon for a miner to get pinned between a wall and the machine, get hit by a loading machine, or get his hand or arms caught in the gears or chains running the conveying machinery. The rapid mining also allowed faster release of methane gases into the mines. Compounded with the presence of electricity to power the machines, explosions became a more frequent occurrence. The darkness and threat of explosion created by dust put off by the machinery also served as a hindrance to safety in the mines, but the most harmful effect of the dust on coal miners was the prevalence of pneumoconiosis, better known as black lung disease. Coal operators refused to accept that coal dust could cause lung disease in miners until the 1960s when it became recognized as a disease under workers' compensation laws, forcing companies to pay annuities to workers suffering from the disease. $^{27}$

As machines replaced miners they had only a few options to fight the rising unemployment in the coal industry. Some miners quit their jobs, some refused to operate the new machinery, and some deliberately sabotaged machinery, but many turned to the United Mine Workers of America (UMWA) to halt the massive changes occurring in coal mining. ${ }^{28}$ Contrary to what the miners needed, John L. Lewis and his union supported mechanization as the only means to heal the ailing coal industry.

Since 1890, the UMWA had sought to provide steady employment and a comfortable "living wage" for union miners, and thanks to the expansion of the coal industry and rise in demand for miners, had largely achieved this goal by 1920 . The

${ }^{27}$ Dix, 92-3, 104-6; West Virginia Department of Mines and Mining, Annual Report (1913-1963). The Elk River Coal and Lumber Company more prevalently utilized mechanical loaders in its Rich Run mine. According to West Virginia Department of Mine reports, the machinery the company used depended on the production levels of the mine. For example, when output was high during the 1940s and 1950s, the company used more mechanical loaders and mining machinery to keep the production pace high.

${ }^{28}$ Ibid, 107. 
sharp increase in demand for coal during World War I stimulated rising employment rates for miners, and reached a high of 750,000 miners employed in 1923. Since the downturn of the coal industry in the 1920s, however, the number of miners has declined ever since. ${ }^{29}$ Faced with high labor wages and the falling price of coal in the 1920 s, coal operators strove to stimulate productivity. They had two choices: intensify labor discipline or replace laborers with machines, and both choices would lead to unemployment in the industry. ${ }^{30}$ It seemed that the natural response of the UMWA would be to fight the coal operators at all costs to save miners' jobs, but John L. Lewis publicly supported mechanization of the coal industry. What were his motivations?

Lewis supported his stance on mechanization in his 1925 book, The Miners' Fight for American Standards. He cited two presidentially commissioned studies on the coal industry as the basis for his decision to mechanize mines, which found that overproduction due to "too many mines and too many miners," was a plague on the ailing coal industry. The United States Bituminous Coal Commission report of March 1920, declared that the United States required less than 500,000 tons of coal per year. Approximately 350,000 miners would be needed to produce that amount of coal. Conversely, the United States coal industry was producing 573,366,985 tons of coal in 1926 and the number of miners employed reached a height of 750,000 in 1923, almost double the number of miners needed in the industry. ${ }^{31}$ Based on those startling numbers it is not hard to understand why Lewis believed a decrease in the number of operating mines and employed miners in the industry was the only saving grace for coal in the United States. Lewis also saw overproduction as a problem for negotiations during strikes because the mass amount of coal being produced permitted consumers to stockpile. Thus, when miners went on strike for higher wages the market was not hurt by the loss of production of coal because a surplus of coal existed that could keep manufacturers and

\footnotetext{
${ }^{29}$ Morris, 20.

${ }^{30}$ Melvyn Dubofsky and Warren Van Tine, John L. Lewis: A Biography (New York: Quadrangle/The New York Times Book Company, Incorporated, 1977), 76.

${ }^{31}$ Lewis, 24; Morris, 24. Morris stated that based on the daily output per man in 1931, 362,000 miners would be required to produce the needed 537 million tons of coal for the United States annual demand. By 1930, there was almost double that number of miners employed, reaching 688,660; Dix, 130. The Bituminous Coal Commission's report of 1920 also supported coal companies' right to mechanize mines without the consent of the union. But, after mechanization, both parties would mutually decide on the rate of pay for miners working machinery.
} 
towns supplied during strikes. Miners had no leverage to negotiate for higher wages because they could not prove how necessary they were in the United States economy. ${ }^{32}$

In order to save the declining coal industry, the UMWA adopted a policy that proposed to "allow natural economic laws free play in the production and distribution of coal." Lewis' policy was based on his belief that both union miners and operators could utilize the capitalist system for the benefit of both parties. Lewis supported large union coal companies in the belief that unemployment and cost-saving machinery would allow wage increases for the remaining miners under the union system. These wage increases would result in a higher purchasing power for the miners who would invest that money back into the U.S. economy. Lewis believed the boost given to the economy would stimulate even more economic development. ${ }^{33}$

Lewis also put forth Darwinian concepts towards the betterment of the industry by supporting the development of large conglomerates in the coal industry. Following the "survival of the fittest" creed, Lewis hoped large companies would weed out the small coal companies causing an evolution in the coal industry, making it much more healthy. Large corporations could afford to bring in new machines that would allow a higher level of efficiency and productivity. The resulting low cost of production by large companies would eventually eliminate small, uneconomical mines that could not compete, ending overproduction and saving the coal industry. Consequently, Lewis connected the UMWA to a policy that would "inevitably bring about the utmost employment of machinery which coal mining is physically capable." ${ }^{34}$ In return, Lewis expected the coal operators not to take advantage of the remaining coal miners by lowering wages. He wrote:

${ }^{32}$ Lewis, 32.

${ }^{33}$ Ibid, 13-15, 41; West Virginia Department of Mines and Mining, Annual Report (1913-1963). Compared with union mines, the Rich Run mine utilized more machinery, even compared to larger union operations such as Consolidated Coal Company. In 1915, Consol averaged eight machines in the mines, while ELRICO had seven. In 1940, Consol again averaged around eight machines in its mines, while ELRICO had twenty-seven machines in its mine. But, by 1950, as operations in Widen reached its peak, machinery numbers began to fall back, as the operation utilized twenty-nine machines. Conversely, Consol's use of machines rose dramatically to thirty-nine, possibly as a result of Lewis' agenda to mechanize union mines.

${ }^{34}$ Dix, 161; Lewis, 108-112. 
[T] he mine worker insists, and will continue to insist, that the introduction of loading machinery and other devices which will revolutionize the industry on its mechanical side, make no difference in the fundamental human side of the industry as now expressed in wage scales, working conditions, and Union relationship, and therefore the mechanical changes to be inaugurated cannot be taken advantage of by management to impair those standards. ${ }^{35}$

As a result of the combined efforts of Lewis and coal companies, mechanization of operations resulted in high rates of unemployment throughout the coal mining regions of Appalachia. But, coal companies soon found ways around paying Lewis' proposed wage increases by operating non-union, discharging workers, and replacing them with machines. Coal operators would then, contrary to Lewis' fight for a fair standard of living, work the remaining miners at less than union wages. By 1925, 60 percent of coal operations were non-union and employment fell 18 percent when 141,000 coal miners lost their jobs during the 1920s. Seeing his ideas of cooperation between the miner and the company failing, Lewis turned to the government for help. ${ }^{36}$

Lewis began lobbying for legislation that would give unions federal protection as well as allow the imposition of federal management of the coal industry. Passage of National Industrial Recovery Act (NIRA) in 1933 granted miners the legal right to choose their collective bargaining agent. As a result of the NIRA, membership in the UMWA rose dramatically; by 1934, 90 percent of working miners were dues paying members of the UMWA. ${ }^{37}$

With the clear majority of workers behind him, Lewis began his campaign to raise wages for union miners. Strikes plagued the coal industry between 1940 and 1960 as Lewis strove to obtain higher wages and benefits. When the coal companies refused to comply, he tried to take these advances by force. An uncompromising situation regarding a new union health care plan resulted in the Secretary of Labor seizing the mines in 1946. With the government in control of the coal industry, Lewis negotiated a

\footnotetext{
${ }^{35}$ Lewis, 116.

${ }^{36}$ Seltzer, 47; Dix, 168-182.

${ }^{37}$ Seltzer, 44; Dix, 186-191.
} 
wage increase and separate welfare funds for pension and health care. These two benefit programs merged to form the Welfare and Retirement Fund in $1947 .{ }^{38}$

In 1950, coal operators formed the Bituminous Coal Operators' Association (BCOA) as their official bargaining agent. The new organization accounted for half of all the coal mined in the United States and soon began trying to control labor costs in the coal industry. During a national strike in 1950, the BCOA, led by George H. Love, obtained an injunction barring UMWA strikes based on provisions of the Taft-Hartley Act. Judge R.B. Kleech ruled against the UMWA, restraining the union from "demanding a closed or union shop, limitation of the benefits of the welfare fund to union member, the 'able and willing' clause, [and] the right to stop work during 'memorial periods." The UMWA did not fight the ruling and it essentially stood for decades afterwards, as no UMWA contract after 1950 contained the right to strike clause. The no-strike policy by the UMWA would lead to decades of unauthorized, wildcat strikes by rank-and-file miners. ${ }^{39}$

The BCOA-UMWA contract of 1950 included benefits to employees, such as hospitalization, retirement, workers compensation, and disability. These benefits were paid by the Welfare and Retirement Fund, which was funded by a 30-cent royalty on every ton of coal mined by union miners. ${ }^{40}$ With incremental raises in wages and Fund royalty payments, Lewis became satisfied with his negations with the BCOA. Yet, rankand-file miners became more and more disgruntled, as payment for benefits did not reach their expectations. By 1952, wages had risen to $\$ 20.25$ a day, yet there had not been a corresponding change in the royalties paid to the Fund. ${ }^{41}$

In the 1950s, Lewis began "organizing drives" to unionize all small companies not operating under his union's control. The organizing drives were based on intimidation and destruction of property with the ultimate goal to organize the miners and bankrupt the non-union company. ${ }^{42}$ It was under these conditions and motivations that

\footnotetext{
${ }^{38}$ Seltzer, 56-59.

39 "UMWA Cited for Contempt of Court as Miners Continue Nationwide Stoppage," Coal Age (March 1950): 141, cited from Seltzer, 64.

${ }^{40}$ Seltzer, 68 .

41 Ibid, 72.

42 Ibid, 73.
} 
the United Mine Workers of America entered Widen in 1952, prepared to unionize the large non-union company at all costs. 


\section{Chapter 3 \\ The Formative Years in Widen: The Reign of "King Bradley"}

The culture of the free miner developed in early coal mining communities, but as operators began to take more and more control over the working environment in coal mines the miner saw less and less freedom in the workplace. A new culture of the miner began to develop in coal communities that featured oppression on the part of operators as they strove to control every aspect of the miner's life. The freedom of the early days of mining was replaced with a quasi slave state in the coal fields. Operators sought to control not only a miner's working environment, but his private life as well. A new form of coal communities thus emerged at the turn of the twentieth century.

In his book Coal Towns, Crandall Shifflett addressed the idea of paternalism in coal company towns of Appalachia. Shifflett declared that coal company owners strove to provide for coal miners in order to achieve a level of contentment among the miners, which would make them more productive. Shifflett defined the attitude the paternalistic coal company operators had towards the coal miner as "contentment sociology." In 1916, the Stonega Coal and Coke Company came to the conclusion that, contentment is necessary for the stability of labor and prevention of unions and lockouts. Playgrounds, amusement halls, night schools, and domestic science classes have been carefully worked out for the benefit and contentment of the employee and his family. Again, the Church, for the first time, is strongly represented at all Collieries, it being such that each denomination has sent to the company one or more of their strongest pastors. ${ }^{1}$

According to Stonega, keeping the miners content through entertainment, education, and religion, would encourage miners to be more productive, and therefore, make more money for the coal company.

Shifflett is quick to defend his characterization of paternalism. He stresses that paternalism in a coal company town had a beneficial side for the miners. Studies have shown that coal miners in Appalachia led a very mobile life, moving from town to town to find work. Because of this mobility, miners in Appalachia could move across the region in search of the coal operator that would provide the most amenities. Shifflett

\footnotetext{
${ }^{1}$ Shifflett, 54 .
} 
stresses the idea that miners benefited from the paternalistic relationship with coal operators, stating that miners even preferred more "interested" coal operators to those that were not involved in their lives at all. Nevertheless, a form of oppression could and did result from this type of relationship in coal towns. A coal miner not only reaped benefits from the services the operators provided, but he also felt the dictatorial hand of the coal operator in many aspects of his life, especially in regard to company housing and the company store. A miner and his family were subject to eviction and this threat of being homeless kept many miners under the thumb of the company, stifling labor uprisings. Shifflett also admits that some coal companies kept miners in place by charging high prices at the store and by paying a portion of paychecks in company scrip. Miners could only redeem scrip at the company store, however, Shifflett stresses that companies rarely used these oppressive tactics. ${ }^{2}$

Many other scholarly works regarding coal mining in Appalachia have clearly disputed Shifflett's image of a coal town. For example, David Alan Corbin depicts a different view of coal mining towns in his book Life, Work, and Rebellion in the Coal Fields. Corbin stresses the importance of worker unity to overthrow the restraints and constraints of the coal operator who only tried to divide and conquer the workers through a system of unequal benefits and living conditions. He emphasizes the tyrannical nature of the coal operator and coal miner relationship by illustrating the merciless evictions carried out by operators and the oppressive systems of scrip, credit, and high prices at the company store.

It is most likely that life in a coal-mining town is found somewhere between these two opposing portraits of community life, or that oppressive conditions for miners coincided with downturns in coal prices. The company controlled its operations and town through a mixture of paternalism and dominance. It is true that the coal town became the central institution of a miner's life; it was the source of his work, his wages, his home, and his social life. Coal miners most likely benefited from the policies of a paternalistic coal operator, and certainly enjoyed the company-built facilities such as

\footnotetext{
${ }^{2}$ Ibid, xv-xvi.
} 
theatres, ballparks, dance halls, churches, and schools, but in return for these amenities, coal companies expected the miners' complete allegiance and submission. ${ }^{3}$

W.P. Tams addresses the issue of paternalism in his book, The Smokeless Coal Fields of West Virginia. Tams' viewpoint is unique because he was a coal operator during the development of the coal industry in southern West Virginia at the turn of the twentieth century. He organized the Gulf Smokeless Coal Company and oversaw the construction of the coal town Tams. In the introduction to The Smokeless Coal Fields of West Virginia, Ronald Eller puts forth the notion that W.P. Tams believed in the notion of "Old South Paternalism." Paternalism in this sense supports the idea that a slave owner represented more than just an owner to his slaves. He could almost be considered a father figure, who cared, protected, and provided for his slaves in order to get the maximum output of work from them. Along these same lines, Tams cared for the miners in his coal town. ${ }^{4}$

Tams addresses the myth of the coal mining town managed by monopolistic, domineering coal operators by asserting that operators created company towns because they had no other option. Coal deposits were located in isolated areas and in order to get the coal mined, laborers had to live near the deposits. Therefore, operators had to provide essentials, such as food and housing for their laborers. Tams points out that coal operators varied in their treatment of miners. Some provided the bare minimum for miners, while others, including himself, provided all they could for their labor force. Tams' viewpoint supports the belief that the operators had a duty and responsibility to create an environment in a coal town that "encouraged order, peace, and stability." Creating this stability would in turn maximize production from the miners and therefore increase profits for the operators. Thus, while Tams supports the belief that it was a duty for operators to provide for miners, he also admits the benefits for the operators as well. ${ }^{5}$

During the height of the coal boom in Appalachia, almost eighty percent of the miners living in southern West Virginia lived in a coal town. Because these new mines

\footnotetext{
${ }^{3}$ Ronald D. Eller, Miners, Millhands, and Mountaineers: Industrialization of the Appalachian South, 1880-1930 (Knoxville: University of Tennessee Press, 1982), 162; Duane Lockard, Coal: A Memoir and Critique (Charlottesville: University of Virginia Press, 1998), 88.

${ }^{4}$ Tams, 5.

${ }^{5}$ Ibid, 5 .
} 
were located in undeveloped areas, up "hollers" in the mountainous terrain of Appalachia, a coal operator was left with no choice but to construct a town for his mine laborers. As a result, the company provided housing for its workers that proved to be adequate for the miners and economically efficient for the company. Constructed out of necessity, more than company benevolence, most coal towns exhibited the same defining characteristics. Coal towns were usually located on the "lower slopes and valley floor between two high ridges." general floor plan:

They were frame boxes, set on wooden foundation posts, with no porches, no running water, and no plaster. The walls were covered with wooden siding inside and out, sometimes lined on the outside with a thinner finishing board. Rent for these shacks was four or five dollars a month, deducted from the pay along with the bill at the company store. We got coal from the company for fifty cents a load. Water was drawn from wells by a bucket. We had a cookstove in the kitchen and a small stove for heat in the front room. The rooms upstairs... were unheated. ${ }^{7}$

These were the conditions for the typical mining town. Some companies provided more services and some provided less for their miners. The Elk River Coal and Lumber Company provided higher than the average housing and amenities for its workers.

As production rose at the new Rich Run Mine in the early decades of the twentieth century, so did the number of miners employed by ELRICO and the number of houses in Widen. In his report as general manager of operations of the Rich Run mine to President J.M. Cameron, Bradley requested better amenities be provided for the employees in Widen in order to draw more men to the mine for work. In order to secure a better class of employees, Bradley requested no two-family homes be built and that yards should be left around each house for privacy and fire protection. Lots provided were 40 feet by 100 feet. $^{8}$

The houses in Widen followed the same floor plan of the typical coalfield settlement housing. The first houses constructed were single story structures with three, four, or five rooms, stone foundations, galvanized steel roofs, and were painted red with

\footnotetext{
${ }^{6}$ Eller, 162-184.

${ }^{7}$ John Brophy, A Miner's Life (Madison: University of Wisconsin Press, 1964), 27-28.

${ }^{8}$ Elk River Coal and Lumber Company Financial Statement 1911 (Charleston: West Virginia
} State Archives Manuscript Collection), 12. 
white trim. Four room homes had 14 feet square rooms featuring tongue-and-groove floors with closets and fireplaces, a kitchen with a stove, and one unheated room. Widen houses had small front porches and a "good sized back porch," but did not have plumbing or electricity. Early rent ranged from $\$ 5$ to $\$ 7.50$ dollars a month. Bradley reported of more houses being built every year in the initial growth period of the town and by 1912, 84 homes had been built. Eventually the town would support around three hundred houses, each with its own yard. ${ }^{9}$

Bradley added ditched and graded streets with narrow boardwalks as the rows of houses expanded. ${ }^{10}$ Each street was given the name of a local county and the town eventually supported and maintained eight streets: Kanawha, Fayette, Nicholas, Braxton, Wood, Roane, Clay, and Buffalo Road, named for Buffalo Creek which ran through Widen. Most of the single homes were located on Nicholas Street. Although Bradley initially requested no double-homes to be built in the town, he eventually built some on Braxton Street. As is the circumstance of most coal towns situated in the hills of West Virginia, none of the streets ran parallel to each other. All the streets ran up a "holler," making a star-shaped pattern out from the center of town. ${ }^{11}$

A single road, leading off of Widen Hill from County Route 7 was the only way into town where it met Fayette Street, which demarcated the "colored" section of Widen. There were only around twenty to forty houses allotted for the African-American workers in Widen and most were located along Fayette Street. Buffalo Creek also ran into town along the same path of Fayette Street and some of the houses and black establishments, such as a barbershop and the African-American church were located on the hillside across Buffalo Creek from Fayette Street. ${ }^{12}$

Kanawha Street was the street for the "bosses" of the mines. The superintendent lived on this street, and the Club House, or the Grille, was also on this street. Opened in

\footnotetext{
${ }^{9}$ Ibid, 12; Elk River Coal and Lumber Company Financial Statement 1910, 13-4. Elk River Coal and Lumber Company Financial Statement 1912, 19-20.

${ }^{10}$ Elk River Coal and Lumber Company Financial Statement 1911, 12.

${ }^{11}$ Lola B. Given, "Memories of Widen," [On-line Document], (July 1997, accessed 25 September 2000); available from http://www.rootsweb.com/ wvclay/claywd.htm; Internet; Clay County Historical Society, History of Clay County II, 79; Wild Wonderful Widen, 3. March 1977): 9.

${ }^{12}$ Barbara Yeager, "Mostly Work: Making a Home in Widen," Goldenseal 3, no. 1 (January-
} 
1912, the clubhouse was a place for office workers and teachers to find lodging and a meal in Widen. In an interview for Goldenseal, Mrs. Mary Forte remembers the Grille as a place where "you could go and buy most anything you wanted to eat, ice cream, drink pop, most any kind of sandwiches."

Striving to keep miners content with their living and working situations in Widen, ELRICO attempted to become the sole provider for miners working in the town. The company supplied electricity to the town in 1913; turbines near the tipple provided electricity to houses, streetlights, as well as the mines. With the new supply of electricity, the town lighted its first Christmas tree in December of 1913. As with many coal company towns, a practice of celebrating the Christmas holiday with the company began that year and progressed through the years in which the company would provide the children of Widen with a treat. The company also built a theater to provide entertainment to the miners in 1914, and established the Bank of Widen in $1918 .^{14}$

W.P. Tams described the development of his coal town. In 1910, the town of Tams supported 125 houses equipped with electricity, a company store, and an office building, and by 1913, Tams had a filtered water system allowing for running water in each company house. The water system in Tams was very much ahead of the typical coal company town. W.P. Tams states that the amenities offered in his town, including the water system and a movie theatre, were not even available in Beckley, the burgeoning county seat of Raleigh County. ${ }^{15}$

The water system in Widen developed far behind Tams, regarding filtering and individual house access. By the year 1938, most homes in Widen were equipped with electricity, but still did not have gas or water. Although the company connected water lines to a deep well located below the tipple to provide a water system for nearly four hundred people living in Widen in 1926, water lines to employee housing did not come about until many years later. The company first laid lines to supervisors' homes, and it

\footnotetext{
${ }^{13}$ Ibid, 10; Given, 2.
}

${ }^{14}$ Clay County Historical Society, History of Clay County II, 80; Shifflett, 54. Shifflett discusses Christmases at Stonega coal town. In 1916 the company gave all its employees and their children a Christmas present. The company agreed the practice was a success making the employees of 1916 the "happiest employees of the Stonega Coke and Coal Company had ever had."

${ }^{15}$ Tams, 67. 
was not until the 1950s that miners' homes received the benefits of indoor plumbing. Prior to that decade, residents had to pump water from hand pumps on the street for a water supply. ${ }^{16}$

Tams and Bradley provided much higher standards of living for their miners than most coal operators. Because of the differing natures of operators, a vast spectrum of living conditions existed in the Appalachian coal fields. A visitor to one coal town may have encountered:

a degrading scene of air turned rancid by surface privies, hogs wallowing in the muddy street, swarms of flies creating a great democracy of germs, mounds of decomposing garbage scattered everywhere, and raw sewage making a foul paste of the streams passing through the settlements. ${ }^{17}$

Towns such as Widen and Tams, although not the best towns in America in which to live, did provide a better quality of sanitation and housing than most coal towns.

In 1947, Admiral Joel T. Boone studied the medical, sanitary, and housing conditions in coal mining towns throughout the United States. Through quantitative data, the study reveals the vast differences in the standards of living in company towns. Surrounding terrain, financial condition of the operator, age of the town, and the anticipated life span of the town all had some part in determining the quality and conditions of life in a coal town. Fifty percent of the houses surveyed had running water piped into the home, yet only 10 percent of company-owned housing had indoor bathrooms. The figure rose to 30 percent in privately-owned housing. Privies were the most common form of waste disposal in many coal company towns and conditions surrounding privies also varied from town to town. Some presented adequate disposal and containment of waste, while other towns' privies contaminated the local water supply. Boone's report reinforces the theory that life in every coal town did not represent

\footnotetext{
${ }^{16}$ Clay County Historical Society, History of Clay County II, 80. The entire population of Widen in 1925 was 368; Yeager, 8; Wild Wonderful Widen, 4-5.

${ }^{17}$ Kai T. Erikson, Everything in Its Path: Destruction of Community in the Buffalo Creek Flood (New York: Simon \& Schuster, 1976), 96.
} 
squalor and poverty but that conditions in coal towns varied greatly, depending on the nature and intentions of the coal operators. ${ }^{18}$

Paternalistic coal operators' believed that miners in good physical condition produced more coal, therefore many hired on-site doctors to live in their company towns and care for their miners. According to Shifflett, the Stonega Coal and Coke Company's theory of contentment sociology deemed "industrial medicine...important because the health of the employee is the biggest production problem."19 Bradley was no different in regards to care for the miners in Widen. As early as 1911, Bradley requested a doctor to be on site in Widen to "guard against accidents and safeguard the life and limb of [company] employees at every point." 20 ELRICO hired a physician from Charleston shortly after Bradley's request to President J.M. Cameron. Dr. Eugene Davis served as the first physician in Widen and was expected to be on call twenty-four hours a day to serve the residents in town. Davis only stayed in Widen a year before Dr. R.H. Eanes of Richmond, Virginia succeeded him as company physician in $1912 .^{21}$

As did most miners in most company towns, employees of ELRICO paid monthly dues for the health care services and in theory their visits to the doctor were supposed to be free. Residents of Cressmont and Swandale had to ride the train to Widen, if doctor's services were required. Dentist and optometrist services were also available to the miners in Widen, yet these services would only be available during office hours and the miners had to pay their own fees at these establishments. ${ }^{22}$

In his study, Admiral Boone addressed the quality of medical service in coal mining towns. The survey found, as was the case in Widen, most miners paid for a physician in advance through a regular deduction from their wages. Boone concluded that the most efficient way for companies to provide medical services was on a prepayment system. In order for a coal company to attract a doctor to work in its town, it

\footnotetext{
${ }^{18}$ United States Coal Mine Administration, Medical Survey of the Bituminous Coal Industry: Report of the Coal Mine Administration (Washington, D.C.: United States Government Printing Office, 1947), 14-60.

${ }^{19}$ Shifflett, 55.

${ }^{20}$ Elk River Coal and Lumber Company Financial Statement 1911, 33.

${ }^{21}$ Clay County Historical Society, History of Clay County II, 80; Elk River Coal and Lumber Company Financial Statement 1912, 21.

${ }_{22}$ Clay County Historical Society, History of Clay County II, 80; History of Clay County I, 40; Wild Wonderful Widen, 4.
} 
had to guarantee a steady salary. Deducting a medical fee every month from the miners' wages guaranteed a minimum salary to the doctor, while also providing the needed medical services that would keep them healthy. ${ }^{23}$

The company store is considered in all studies of the Appalachian coalfields as the nexus of community activity in coal towns. Some scholars have long considered the company store a representative of oppression over the miners by the coal companies. In many towns the coal companies paid miners in scrip redeemable only at the company store, where prices on goods were highly inflated. In Life, Work, and Rebellion in the Coal Fields, Corbin states that "U.S. senatorial investigating committees repeatedly revealed that the region's coal company store prices were substantially higher, sometimes three times higher, than the local trade stores. ${ }^{24}$ Other scholars see the company store as a community gathering place that stimulated the culture of the coal town and believe that coal companies offered miners the chance to avoid "owing their soul to the company store." Crandall Shifflett asserts that because miners had the choice to buy goods from other establishments located outside of town, a conscious effort was made to stay out of debt. He believes the company store provided a community meeting place and should be viewed in those terms, not as an oppressor of the miner. ${ }^{25}$

According to economist Price Fishback, companies would not charge exorbitant prices because the prices at the company store were part of the overall employment package companies offered to lure miners to work for them. Although wages and conditions in the mines were the major factors in a miner's decision to work for a certain coal company, the prices at the company store also had an effect on the decision of the mobile laborer. As a result, a company that had high prices at the store would have to compensate by offering higher wages and more amenities in town. Other factors such as geographic isolation, transportation costs, and the presence of the union also affected the prices at company stores. Fishback explains the need for a company store in a coal town. Coal companies took a risk by opening their own store, but it was a risk to benefit the coal miners. Fishback argues that companies continued to operate stores not because of

\footnotetext{
${ }^{23}$ U.S. Coal Mine Administration, 115-116.

${ }^{24}$ Corbin, 10.

${ }^{25}$ Shifflett, 182.
} 
the assumed high profits they were making, but because of the lowered "information and enforcement costs of credit" and to protect miners from being overcharged by independent stores. As a result, many company stores actually offered lower prices than local independent stores. ${ }^{26}$

W.P. Tams illustrated the company store as just another amenity provided by the company to its miners. Because the coal towns were isolated, it proved difficult to get supplies from outside sources. In order for miners to have food and clothing, as well as mining supplies, the company established a store to make these goods readily accessible to the miners. Tams admitted that some coal operators took advantage of the near monopoly on the sale of goods and charged excessive prices at the company store, but other companies "operated on a profit margin considerably below that general among private stores in the area." Tams also addressed the controversial subject regarding the issuance of scrip as pay by the coal operators. Tams' company only issued scrip as a form of credit, an advance on a miner's pay. Therefore, generally his miners received cash on payday, but if one needed credit at the store, it would be issued in scrip. ${ }^{27}$

In his memoir, Duane Lockard supports Tams' assertions regarding the issuance of scrip. "Some [companies] would advance scrip in anticipation of earning, thus putting miners in debt, but the Consolidation Coal Company in my day granted scrip only if the income had already been earned." Yet, Lockard also goes on to support Corbin's theory of company store inflation and manipulation. "Scrip was good at face value only in the company store; non-company businesses elsewhere discounted it by as much as 15 percent. Either way, since prices were higher in company stores, scrip's value was inevitably less than that of coin of the realm." Lockard stated the quality of goods in the company store were lower, yet prices higher than the goods in local privately owned, or

${ }^{26}$ Price Fishback, "Did Coal Miners 'Owe Their Souls to the Company Store'? Theory and Evidence from the Early 1900s," Journal of Economic History 46, no. 4 (December 1986): 1011-1016. Information and enforcement costs of providing credit were lower for companies because they controlled the wages issued to its employers, which made it easier to collect on the credit owed the store than an independent store. Fishback also believes that companies ran stores to prevent independent stores from developing a monopoly and then charging high prices to miners.

${ }^{27}$ Tams, 7,52. 
chain stores. As a result his family had to save cash to buy certain products elsewhere than the company store. ${ }^{28}$

The Elk River Coal and Lumber Company established a company store in Widen in 1912. By 1925, the three-story store building not only housed the store, but also a post office and offices for the company. A percentage of the miners' pay was issued in company scrip, redeemable only at the company store. The Elk River Coal and Lumber Company supported company stores in Widen, Dille, Swandale, and Dundon. These stores provided everything a miner could possibly need. The largest company store, located in Widen, was one of the largest buildings in Clay County and housed the only ice plant in the county. Despite the monopoly on business in Widen, the company took steps against abusing its miners. Bradley admitted the company store had a "complete monopoly" in Widen, but that the monopoly "should not be abused [by the company] and employees driven away by the high prices." 29

Although Widen was a seemingly remote town, located in a valley surrounded by steep hills, the opportunity to buy from non-company stores did exist there. The small town of Dille is located only a few miles from Widen and several privately-owned stores were located there, from which miners could buy goods. Yet, this type of economic freedom only became readily available after the advent of the automobile age, allowing miners transportation to not only buy goods outside of town, but also live outside of the company town. But, residents of Widen did not have to go out of town for any provisions unless they chose to. A woman could "go to the store and get any kind of meat you wanted, any kind of dress you wanted, even buy your furniture, go to the bank and get your scrip cashed. ${ }^{~} 30$

As more and more miners came to coal camps for work, their families followed them to these developing coal towns. In order to make their "employment packages"

\footnotetext{
${ }^{28}$ Lockard, 88-89.

${ }^{29}$ Wild Wonderful Widen, 4; "Widen: An Appalachian Empire," 11; Yeager, 10; Elk River Coal and Lumber Company Financial Statement 1912, 14.

${ }^{30}$ Yeager, 9. Residents of Widen could and did ride the passenger train that ran from Widen to Dundon. Thus, it is possible residents could have traveled to Dundon and go to Clay to shop, but it is most unlikely Widen residents would have made the 36- mile round trip just to purchase groceries from a noncompany business. In regards to her quote about shopping in Widen, Mrs. Forte does not indicate whether the scrip was cashed at full value, but since the Bank of Widen was owned and operated by Elk River Coal and Lumber Company, it is most likely it would be cashed at face value.
} 
more appealing, companies had to start providing for the education of the children of their miners. Trying to avoid the underemployment and lack of funding experience by the typical county school system in Appalachia, many coal companies gave aid to the school system in its town to provide a better education for its miners' children. The result meant that coal towns would have a school, which the county superintendent of schools administered, but the company provided the building, supplies, and sometimes teachers for the daily operation of the school. ${ }^{31}$

In 1911 a one-room school opened in Widen, with a capacity of seventy students. Because of the growing number of miners coming into the town with children, a second room was added in 1912, and by 1921 the elementary school had 150 students with eight teachers. A junior high opened in 1928 and the Widen High School opened in 1932, graduating eight in its first year. Before that year students had to ride the train to Clay High School in Clay. ${ }^{32}$

ELRICO teachers were paid well and were expected to abide by company rules.

Mr. Parker C. Black wrote of his dealings with Bradley and Widen's educational system:

[Bradley] had wealth and power and was somewhat aloof, but he had the interests of his people at heart. He paid salaries far above the prevailing scale in order to attract the most competent people and to prevent the Unions from organizing his industries. If ever there was a fiefdom in the United States, that area was it. But it was a benevolent government and most of the people liked it. I went to Widen in 1925 as principal of a tenteacher elementary school. Mr. E. T. Price was the general superintendent of the coal operations. He...governed completely. But...if one did his job well, he had nothing to fear; but if one were remise [sic], he did not last long.

Mr. Parker goes on to talk about his interview with Price for the job as principal. Price made it clear to Parker that in return for high teacher salaries he expected loyalty from the educators in Widen:

\footnotetext{
${ }^{31}$ Eller, 187.

${ }^{32}$ Clay County Historical Society, History of Clay County II, 81.
} 
I will pay you twice what you are now getting. All I ask is your loyalty. I do not know anything about running a school, but I do know when a man makes a major mistake, and if you make one, I'll sure as hell tell you so! I do not want to be bothered. You run it. Organize it, employ your own teachers, offer teachers $\$ 15.00$ a month beyond the state pay and we will pay the extra, make your own budget and buy your own equipment.

Those were my instructions when I went there and I made the most of it.

Mr. Parker emphasized the fact that ELRICO paid teachers in Widen much higher wages than the teachers working in the surrounding areas. He stated that he persuaded the superintendent to pay a teacher in Widen \$15 a month the first year, \$20 a month the second year, and $\$ 25$ a month the third and subsequent years. ${ }^{33}$

As in most coal towns, education of white and African-American children in Widen was segregated. The segregated educational system in West Virginia required at least an elementary school in a community with ten or more black children. As the African-American population in Widen rose, the requirement to provide an educational facility for black children presented itself. In response, Bradley built an AfricanAmerican school in 1914, providing education for the black children in Widen up to the eighth grade. The school was one-room with one teacher for all the grades. Before integration, when black children finished the eighth grade they had to leave Widen to attend high school either in Institute or Clarksburg. Mrs. Forte spoke of the educational situation for blacks in Widen:

The Board of Education paid $\$ 30.00$ a month for each child that had to go away to school, and the people they boarded with, they were charging $\$ 40.00$ a month for the boys and $\$ 30.00$ for the girls. The parents had to make up the difference when they sent boys to high school. ${ }^{34}$

Joe Trotter notes in his book Coal, Class, and Color, that despite the segregation of educational facilities and the exclusion of African-Americans from higher education institutions in the state, black education in West Virginia received "a relatively equal, and sometimes disproportionately high, percentage of state aid." Still, black facilities lagged

${ }^{33}$ Cantrell, et al, 4-5.

${ }^{34}$ Joe William Trotter, Coal, Class, and Color: Blacks in Southern West Virginia, 1915-1932 (Urbana: University of Illinois Press, 1990), 135; Yeager, 10; Wild Wonderful Widen, 4,6. After integration in 1951, all the children in Widen attended Widen High School until it closed in 1962, whereupon they were bused to Clay High School in Clay. 
greatly behind white educational institutions in West Virginia. Trotter acknowledges that while the state began building new high schools for white children, the process of establishing higher educational facilities for blacks lagged behind. As a result, "where counties failed to establish black schools, especially high schools, black parents were forced to send their children elsewhere for post-secondary education, sometimes even out of the state. Few black coal-mining families could afford to, though."35

As Bradley built his town, production of coal from the Rich Run mine continued to grow. The average production of coal doubled every decade until World War I, where it leveled and then began to decline in the 1920s. World War I resulted in a new image of the coal miner and his role in the world economy. The coal miner became a patriot. His work provided coal, which fueled the defense of the free world. As a result of the high demand for coal, companies made fortunes, yet production at Widen dropped around 1917 and continued to fall until 1918, when workers began coming home from the War in Europe. Production rose in 1918 to 260,982 tons and then to 481,771 tons per year in $1922^{36}$

Elk River Coal and Lumber Company Operational Statistics

\begin{tabular}{|c|c|c|c|c|}
\hline Year & $\begin{array}{c}\text { Number } \\
\text { Employed }\end{array}$ & Tons Produced & Days Worked & $\begin{array}{c}\text { Number of } \\
\text { Machines Used }\end{array}$ \\
\hline $191 *^{*}$ & 32 & 18,219 & 210 & 3 \\
\hline 1912 & 106 & 131,188 & 235 & 7 \\
\hline 1913 & 170 & 200,416 & ----- & 7 \\
\hline 1915 & 271 & 435,12 & 309 & 11 \\
\hline 1920 & 264 & 338,931 & 257 & 14 \\
\hline 1925 & 338 & $1,023,052$ & 310 & ----- \\
\hline 1930 & ----- & 555,155 & ----- & --- \\
\hline 1935 & 550 & 635,415 & 287 & 27 \\
\hline 1940 & 458 & 763,819 & 310 & 29 \\
\hline 1945 & 551 & $1,083,953$ & 382 & 17 \\
\hline 1951 & 600 & 874,446 & 250 & ----- \\
\hline 1952 & 600 & 675,799 & 183 & ---- \\
\hline 1960 & 235 & 689,511 & 246 & 238 \\
\hline 1963 & 247 & 706,379 & & \\
\hline
\end{tabular}

Figure 1 - Data derived from West Virginia Department of Mine Annual Reports 1910-1963. *1910 data reflects operations of ELRICO Dundon mine before the Rich Run mine opened.

\footnotetext{
${ }^{35}$ Trotter, 136.

${ }^{36}$ U.S. Coal Mine Administration, xiv; Corbin, 187; Clay County Historical Society, History of Clay County II, 80-81.
} 
After the war, as production rose in the Rich Run mine, so did the population of Widen. Citizens began taking an active part in the development of the "community" of the town. Social organizations began to develop in Widen in the 1920s. That decade saw the organization of the Women's Club and the Rotary Club. Mrs. Frank Kennedy organized the Women's Club in 1925 and the group became a member of the General Federation of Women's Clubs in 1929. The Women's Club helped sponsor Red Cross drives, bake sales, and hosting Mother and Daughter Banquets. The Rotary Club was established on June 19, 1929 and organized social events such as Father and Son Banquets, as well as celebratory events for the graduating classes of Widen High School. Still endeavoring to make his town a respectable place, Bradley began to develop amenities that would provide entertainment for his miners that could deter the illegal consumption of alcohol on the weekends and the problems it created, such as violence and illness. ELRICO built the first and only Young Men's Christian Association building in Clay County. The first building housing the Y.M.C.A. burned down 1920, but was rebuilt that same year. The building had a soda fountain, skating rink, bowling alley, beauty and barbershops, poolroom, and an auditorium. The Y.M.C.A. also supported a Hi-Y club that organized rummage sales, plays, and a Boys' Week. ${ }^{37}$ The Widen News, which announced events and featured local interest stories, began publishing monthly in 1921. ELRICO later took over publication, increasing the circulation to include news from Dundon, Swandale, and Cressmont. Through this company publication, Bradley had a vehicle to promote company policy and standards. ${ }^{38}$

Like many coal mining towns in Appalachia, the citizens of Widen had very strong ties to religion. Corbin contends that religion provided protection for miners. Miners constantly lived with the threat of death, and religion was their solace. Knowing that a greater reward was in store for them, if death would come in the mines, gave the miners more support than any of the other services Bradley could provide for them. Filling the need for religion, there were usually two or three churches in a coal company

\footnotetext{
${ }^{37}$ Clay County Historical Society, History of Clay County II, 81-82.

${ }^{38}$ Wild Wonderful Widen, 5.
} 
town. Widen was no exception and eventually supported up to five church denominations. ${ }^{39}$

Reverend Louis Black of Parkersburg established the first Sunday school in Widen in 1914. A Catholic Church was built in 1917, but a flood destroyed it in 1926. The Catholic congregation moved meetings to homes across Buffalo Creek until it eventually dissolved in 1930s. Although Widen had a Sunday school, it had no permanent minister until the community church was established in 1929. But, due to financial difficulties, the church and parsonage were not built and the church was once again left with no minister for seventeen months. The Widen Baptist Church was organized on February 17, 1934, and the Widen Baptist Sunday School was organized on October 21, 1934. The Church held services in the old theater building until 1961, when it moved into a new building, primarily constructed through voluntary labor of the congregation, across Buffalo Creek. The Elk River Coal and Lumber Company donated the land on which the church stands to this day. ${ }^{40}$ There were also Presbyterian and Methodist as well as an African-American church in Widen and most of the black families in Widen belonged to the church. A traveling minister would come to Widen to preach on Sundays until the African-American church obtained a permanent preacher, who was also a miner in the Widen mines. ${ }^{41}$

After the initial rapid take-off period, the mines at Widen began to experience a reduction in hours and wages during the Depression years (see Figure 1). Nevertheless, work rarely fell below an average of two working days per week, and in 1933, miners even averaged five days a week. ${ }^{42}$ Still, working only two to three days a week did little to provide for a miner and his family. Billy Facemire, a second-generation Widen miner, admitted his father was forced to move out of company housing in Widen in 1930 because he could not afford to pay the four-dollar a month rent. ${ }^{43}$

\footnotetext{
${ }^{39}$ Corbin, 166; Eller, 187.

${ }^{40}$ Wild Wonderful Widen, 4-5; Cantrell, et al, 3; Clay County Historical Society, History of Clay County II, 80; History of Clay County I, 107.

${ }^{41}$ Yeager, 9.

${ }^{42}$ Clay County Historical Society, History of Clay County II, 81; Wild Wonderful Widen, 5.

${ }^{43}$ Billy G. Facemire, interview with author, 17 March 2001, Dille, WV.
} 
Hard times fell on the coal company as well during the Depression. Many of the investments made by the Philadelphia bank and the other stockholders of the Elk River Coal and Lumber Company were losing money. Also, trustees for their heirs of the original stockholders of ELRICO raided the trust and took the profits made by the mines in Widen and by Widen miners, in order to maintain the lavish lifestyles in New England to which they had grown accustom. Despite previously stated problems, the company continued operations as normal during the 1930s. As a result, profits fell significantly, and the company even saw large deficits accrue during the Depression years. ${ }^{44}$

Even though it was losing money and miners were being forced to leave the company town for cheaper living conditions, the Elk River Coal and Lumber Company appeared to be providing more work than any other business in the region. As a result, workers began to pour into the town looking for jobs, causing overcrowding in some sections of town, especially the ethnic and racially segregated neighborhoods.

Widen was so crowded that you just couldn't get any place to stay. People were just living, you know, I'd just say, on top of each other. Houses were filled. So we lived with his, my husband's sister for three years before we could get a house. You were put on a waiting list with the company. You went down and you signed for a house. $\$ 45$

Although the major unionizing campaign conducted by the United Mine Workers of America (UMWA) in Widen occurred in the 1940s and 1950s, efforts to unionize the large non-union operations there started much earlier. The first attempt of the UMWA to unionize Widen occurred in 1912, a time when a mixture of immigrant and local miners made up the workforce in Widen. Bradley claimed the UMWA found little success in organizing the local miners, yet "they got the immigrants stirred up to the point where there was not only friction between the immigrants and the company but between immigrants and natives as well." ${ }^{46}$ The ethnic make-up of Widen reached its most diverse around 1915 and started to decline after the 1930s (see Figure 2). Thus, it can be

${ }^{44}$ Clay County Historical Society, History of Clay County I, 45; Craig Thompson, "Reign of Terror in Widen, W.Va.," Saturday Evening Post, 20 February 1954, 1.

${ }^{45}$ Yeager, 7; Clay County Historical Society History of Clay County II, 80. The Clay County Historical Society states that only 12 "colored" families lived in Widen in 1912. The population quickly rose to the overcrowded population Mrs. Forte spoke of by 1935. Yeager makes clear that this type of overcrowding was not a common occurrence in the white sections of town.

${ }^{46}$ Thompson, 19. 
believed that the UMWA targeted the high number of foreign workers at Widen for its organizing campaign of $1912 .{ }^{47}$

In 1933, the employees of ELRICO established an independent union called Widenra. The name was made up of Widen and the initials of the National Recovery Act. The National Industrial Recovery Act (NIRA), enacted on June 16, 1933, provided that workers had the right to choose their own representation that would collectively bargain with their employers. The United States Supreme Court eventually ruled the act unconstitutional, and in response, Congress passed the National Labor Relations Act (NLRA) in 1935. Under the NLRA, "employees have the right to self-organization, to form, join or assist labor organizations to bargain collectively through representation of their own choosing." A National Labor Relations Board (NLRB) election can be called when a majority of the workers believe that they are not being justly represented by their current representative body and want to elect a new representative. If the workers choose new representation, and the management refuses to voluntarily recognize the union that the workers have chosen, an election can be called. The workers will vote with a secret ballot, and the representative body with the most votes will become the workers representative to the company. ${ }^{48}$

${ }^{47}$ United States Bureau of the Census, Census of the United States: Population (Washington, D.C.: United States Department of Commerce, Bureau of the Census, 1920-1960). According to United States Census Bureau reports, the ethnicity of Clay County was mostly native whites. Widen's ethnic population was higher than the rest of the county. After the 1930s, the foreign ethnicities began to decline and the population of Widen was made up of mostly African-American and native whites. But, when the mines closed in Widen, its ethnic population went down as African-Americans moved out of the town. As a result the non-white population of Clay County declined.

${ }^{48}$ Harry A. Millis and Emily Clark Brown, From the Wagner Act to Taft-Hartley: A Study of National Labor Policy and Labor Relations, (Chicago: University of Chicago Press, 1950), 27-28; William E. Fulmer, Union Organizing: Management and Labor Conflict (New York: Praeger Publishers, 1982), 1215. 
Ethnicity of ELRICO Workers 1910-1930

\begin{tabular}{|c|c|c|c|c|c|c|}
\hline Ethnicity & $\mathbf{1 9 1 0}$ & $\mathbf{1 9 1 2}$ & $\mathbf{1 9 1 3}$ & $\mathbf{1 9 2 0}$ & $\mathbf{1 9 2 5}$ & $\mathbf{1 9 3 0}$ \\
\hline White & 16 & 40 & 70 & 105 & 519 & 592 \\
\hline Black & -- & 8 & 17 & 12 & 74 & 66 \\
\hline Italian & 2 & 20 & 30 & 27 & 5 & 5 \\
\hline Polish & 12 & 4 & 5 & 10 & 9 & 10 \\
\hline Austrian & -- & 10 & 35 & 39 & 7 & 4 \\
\hline Hungarian & -- & 12 & 5 & 12 & 34 & 24 \\
\hline Slavish & -- & -- & 8 & 16 & 10 & 4 \\
\hline Lithuanian & -- & 4 & -- & -- & 3 & 1 \\
\hline Croatian & -- & -- & -- & 12 & -- & 1 \\
\hline German & -- & -- & -- & 8 & -- & -- \\
\hline Horwatt & -- & -- & -- & 9 & 2 & -- \\
\hline Russian & -- & -- & -- & 4 & 6 & 2 \\
\hline German & -- & -- & -- & 8 & -- & -- \\
\hline Spanish & -- & -- & -- & -- & -- & 2 \\
\hline Irish & 2 & -- & -- & -- & -- & -- \\
\hline Bohemian & -- & 8 & -- & -- & -- & -- \\
\hline Unknown & -- & -- & -- & -- & 2 & 2 \\
\hline Total & 34 & 106 & 170 & 271 & 671 & 715 \\
\hline
\end{tabular}

Figure 2 - Data derived from West Virginia Department of Mine Annual Reports 1910-1930. *1910 data reflects operations of ELRICO Dundon mine before the Rich Run mine opened.

It was during the time of Widenra that UMWA District 17 President, William Blizzard, began his first attempt at organizing Widen miners. The company claimed that Blizzard came into town and began holding organizational meetings. During the three months in the town the response to the UMWA diminished, and seeing that he was getting nowhere, Blizzard left town. Blizzard's story differs from the company's viewpoint. He stated, "[w]e went in, but they just rounded us up and shipped us out again, and that was that. I didn't make an issue of it." The NLRB later dissolved Widenra because of company domination in the mid-1930s. ${ }^{49}$

In 1938, after the dissolution of Widenra, the miners organized a new representative body called the League of Widen Miners. The NLRB certified the "League" as the representative agent for the miners in 1946, and the League and the company immediately agreed on a contract that extended through $1955{ }^{50}$ In 1941 , the

\footnotetext{
49 Thompson, 19.

${ }^{50}$ Wild Wonderful Widen, 5-6.
} 
UMWA, under Blizzard's leadership, challenged the League of Widen Miners. The biggest disadvantage to Blizzard was that mining prospered during the war years, and most miners in Widen were satisfied with their wages. Therefore, they did not seek or desire UMWA representation.

In 1941, the UMWA used much more force in trying to organize Widen miners. Bradley claimed that Blizzard sent 200 to 300 UMWA men to Widen who took positions in the hills surrounding Widen and began firing down on the town. In response to the ambush by the UMWA, his employees retrieved their firearms from their homes and began firing back at the men in self-defense. In contrast, Blizzard claims that the company fired upon his men first and that his men shot back merely in self-defense. The gun battle resulted in one death; a state police superintendent died of a heart attack during the gunfire. ${ }^{51}$

The UMWA's next attempt at unionization in Widen came in 1944. Citing provisions of the NLRA, Blizzard demanded, and received, a NLRB election. The League of Widen Miners won the election of 1944, but by a narrow margin. Many eligible miners did not vote and many others deliberately sabotaged their ballots. Neither the UMWA nor the League obtained a majority of the votes, but the League won by a plurality of eight votes. Along with the NLRB election, the clash of 1944 also featured a deadly conflict between a union and non-union man. E.H. Foley, a union organizer, shot and killed Joe Groves during an argument. A fistfight commenced between Foley and Groves, and during the mayhem, Foley pulled a gun, shooting Groves. Foley pled selfdefense, but two separate juries convicted him of second-degree murder in 1944 and 1946. The West Virginia Supreme Court eventually reversed his conviction based upon technical grounds. ${ }^{52}$

In 1946, President of the UMWA, John L. Lewis, demanded that operators pay a royalty on every ton of coal produced in union mines. The royalties would be used to

${ }^{51}$ Thompson, 80 .

52 Ibid, 80; "Foley Given Five Year's Term, Case Will Be Appealed," Clay Messenger, 12 November 1946. A Clay County jury convicted Foley of voluntary manslaughter in November 1944 and sentenced him to five years in jail. Foley appealed to the State Supreme Court, which granted him a new trial. Foley's trial of October 1946 resulted in the same conviction and sentencing, which Foley appealed again and the State Supreme Court eventually overturned. 
establish and maintain a Welfare and Retirement Fund for union miners and their families. Coal operators rejected Lewis' demand and in return, he called for a nationwide strike. On April 1, 1946, union mines across the country shut down. ${ }^{53}$

In Widen, however, mines continued to operate. On April 4, the contract stipulating the League of Widen Miners as the collective bargaining agent for miners in Widen ran out. The miners were faced with the decision to keep the League or to turn to the United Mine Workers of America, engrossed in a nationwide strike. Weighing the options between the two bargaining agencies, the miners chose the League to continue representing them. Widen miners experienced more work and higher wages than UMWA miners and wanted to continue that prosperity. According to the Clay Messenger, basing its facts on the West Virginia Department of Mines report of 1944, the mines at Widen operated 306 working days, compared to 258 days worked in UMWA mines. The extra days of work resulted in miners in Widen making $\$ 3,148$ in 1944, unlike the union miner who averaged only $\$ 2,846$ that year. The paper went on to base the miners' decision to keep the League as bargaining agent on the fact that grievances could be settled at the local level, not relying upon a national strike to gain benefits. ${ }^{54}$

The federal government seized control of mines across the country on May 22, and Lewis began to bargain for his welfare program once again. Secretary of Interior, J.A. Krug and Lewis agreed on a contract for union miners nationwide which included a welfare fund financed by a five-cent per ton royalty and stipulated that the government would continue to operate the coal industry. Mines began production but closed within weeks because Lewis claimed the government had violated the contract. Lewis was fined $\$ 3.5$ million dollars for contempt for the breach of contract, yet he continued to fight for coal miners' welfare fund and higher wages. In July 1947 he signed a new contract with coal operators that raised the welfare fund royalties to ten cents a ton. That same year the coal industry reached an all-time high in coal production at 630 million tons. ${ }^{55}$

\footnotetext{
${ }^{53}$ A.F. Hinrichs, United Mine Workers of America and Non-Union Coal Fields (New York: AMS Press, 1968), 17-30.

54 “Long, Bitter Coal Strike Predicted; Widen League Miners Stay In Pits," Clay Messenger, 2 April 1946.

${ }^{55}$ Hinrichs, 17-30.
} 
Production continued to rise to all-time highs by 1950 in Widen (see Figure 1). Total production jumped from 678,503 tons in 1948 to 1,068,993 tons of coal produced per year in 1949, and work days for the miners at Widen continued to be more than the average workweek for most mines in West Virginia. In 1949, the Rich Run mine worked 300 days, more than any other single mine in West Virginia. ${ }^{56}$

Lewis continued to raise the bar for miners' benefits and wages. By February 1950, he had negotiated another contract raising welfare fund royalties to thirty cents per ton. But in 1951, Lewis signed a contract allowing big coal companies free reign in mechanization and consolidation of coal mines. As a result, over 300,000 miners lost their jobs and thousands of smaller mines closed. Many miners had no choice but to turn to non-union coal companies for work or find work in another industry. ${ }^{57}$ It was under these conditions that the UMWA would begin its greatest struggle for union representation at Widen.

${ }^{56}$ West Virginia Department of Mines and Mining, Annual Report (1949), 24-5; Ibid, 1948, 26-7.

${ }^{57}$ Brit Hume, Death and the Mines: Rebellion and Murder in the United Mine Workers (New York: Grossman Publishers, 1971), 20-24. 


\section{Chapter 4 \\ The Rebellious Years: Widen At War}

Miners in Widen walked out on strike in September of 1952, complaining of an unfair welfare program, poor medical programs, and the lack of an injured worker's compensation plan. Joe Smith, a striking miner, stated one of the main reasons the men walked out on strike was that they did not feel that their jobs and benefits were secure at Widen. "We felt the need for a union that would really represent our interest like the UMW. When you belong to the UMW and go to a hospital, they take you in and if they don't have room there you go to a hospital of your choice." Widen miners felt the company controlled the union and wanted representation that specifically looked out for the welfare of miners, not the company.

Despite the seemingly obvious advantages of the League, Widen miners claimed they were not adequately receiving League benefits and would profit more by joining the ranks of the United Mine Workers of America. The wages for miners in Widen averaged two dollars a day more than UMWA wages and the League's welfare fund provided for larger benefits than the UMWA while the miners in Widen paid only fifty cents for monthly dues compared to the two dollar a month dues for the UMWA. The miners also claimed company domination of the League: "The league is controlled by the company. They've never had an open meeting to discuss our problems with us." ${ }^{2}$ Thus, the miners walked out, protesting the unfair labor practices of the Elk River Coal and Lumber Company. The violence, which resulted over the fifteen-month strike, left Widen in a near state of civil war.

The first stirring of trouble ca me on September 3, when the company fired Jack Hamrick. The superintendent of the mines had assigned Hamrick to work in a trackless section of the mine testing new equipment, but Hamrick claimed that the work was too dangerous, and instigated a disruption among the miners. Brandishing a broken bottle, Hamrick almost injured Harold L. Beattie, the production engineer and acting mine superintendent. As a result of the outburst, Beattie fired Hamrick. The company felt that

\footnotetext{
1 "350 Employees on Strike at Widen, Local Grievance Given as Reason," Clay County Free Press, 2 October 1952.

2 James F. Dent, "Widen Mine Pickets Continue Human Barricade Into $11^{\text {th }}$ Day," Charleston Gazette, 3 October 1952.
} 
if Hamrick had a problem working in the section he should have complained and been reassigned back to his old job, instead of causing a violent outburst. Miners, on the other hand, felt the company had given Hamrick no choice but to work in the unsafe conditions; when he refused, the company fired him. ${ }^{3}$

The next day, miners held a mass meeting to protest Hamrick's firing, but the meeting soon turned into a protest against company policies. Men not only charged the company with neglect and domination of the League of Widen Miners, but also that the League's officers were spending funds and misrepresenting miners at meetings. Some miners believed older, company controlled miners dominated the League and wanted younger miners instated as new officers in the company union. Younger miners, they believed, would bring about changes that coincided with the changing times in the coal industry. Miners aired their grievances throughout the morning and the meeting grew so large it had to be moved to the baseball field and caused the mines to shut down for lack of workers that day. ${ }^{4}$

Harry Gandy, Bradley's assistant, addressed the miners at the baseball field and urged them to return to work. The miners eventually agreed to go back to work, but only after they appointed a committee of seven to represent them and push for reforms in the League of Widen Miners. The committee met with Gandy on September 4 and 19 as employees of ELRICO, not a bargaining committee for the miners. Gandy informed the group that the company had the right to hire and fire miners at will and would not relinquish that right. He made clear that any problems miners had with the League should be taken up with the League, not with the company. ${ }^{5}$

Bradley spoke of the meetings later and admitted he heard the grievances by the men and thought they acted "straightforward and manly" about the situation. He then assured the men that all the pensions and payments for disabilities or assistance had been paid by the company in a regular fashion and would continue to be paid. He noted that other grievances about safety and working conditions were addressed in the mines as

\footnotetext{
3 “News From Widen Coal Mine,” Widen News, 24 September 1952; Frank A. Knight, “Company and Strikers Dispute Effect of Speed-Up," Charleston Gazette, 25 May 1953. The Gazette reported later statistics showed the "unsafe" section Hamrick complained of was worked without a serious accident between September 1952 and May 1953.

4 “News From Widen Coal Mine," Widen News, 24 September 1952; Thompson, 80.

5 Thompson, 80; Widen News, 24 September 1952.
} 
soon as possible, and believed these meetings would settle grievances and be the end of the dispute. ${ }^{6}$

In addition to grievances, the meetings with Gandy also addressed the recent vacancy on the League's Bargaining Committee as a result of the death of Omar Wilson. Wilson's death opened a door for unsatisfied miners to elect a younger miner as a representative on the League of Widen Miners. Under the League's by-laws, President Lanty Facemire had the power to fill the vacancy, but Bradley suggested the committee of seven representing the miners vote through secret ballet to decide who should fill the vacancy. The committee elected Doyle Waggoner and Facemire appointed him forthwith. ${ }^{7}$ The UMWA soon approached Waggoner to seek his support for the UMWA organization of Widen. Waggoner's account of the visit is as follows:

They said they were working for the UMW, and showed me a letter. It was signed by Bill Blizzard...[he]says he does not want to be identified with the strike at Widen just yet, but that he has asked John L. Lewis to send out an organizer from the international union, and that Lewis is going to send Ed Heckelbach. So I asked them why they came to me. They said, 'We want you to help get the men out.' I told them I didn't want to get the men out. Then they said, 'Blizzard has got $\$ 200,000$ to spend on this, and it's a chance to make some money.' I told them I didn't want that kind of money, and they went away. ${ }^{8}$

Finding no support from Waggoner, the UMWA shifted its hopes to Dennis Zirkle to bring unionization to Widen. Zirkle, Hamrick's brother-in-law, had been an instigator of the walkout on September 3. He had worked for years in the mines at Widen, and was known as a "good, careful, and productive miner." Zirkle claimed he had gone to organizing school during a brief period of time that he lived away from Widen, and that the UMWA sent him back to the town to organize it. Yet, William Blizzard denied Zirkle's connection to the UMWA and claimed that "Zirkle never worked for the UMW and he never worked under a UMWA contract. Nor was he ever the leader of that strike down there." Despite Blizzard's protests, it appears that Zirkle clearly instigated several of the walkouts in Widen, provoking the eventual strike.

\footnotetext{
${ }^{6}$ J.G. Bradley, "Restatement of Situation at Widen," Widen News, 29 January 1953.

${ }^{7}$ Thompson, 80.

${ }^{8}$ Ibid, 84.

${ }^{9}$ Ibid, 80 .
} 
On September 21, Zirkle persuaded the men on the Number 1 and Number 2 shifts not to go to work. What seemed to be a response to Waggoner's refusal to help the UMWA, Zirkle claimed that Bradley and the League of Widen Miners had doublecrossed the miners. Zirkle urged the men to go on strike because the only way Widen miners could have adequate representation and rights was through the UMWA. The men quickly created a picket line around the washhouse, keeping many miners from working either because of support for the walkout or from the sheer confusion the pickets created around the mines. ${ }^{10}$

Miners claimed they had walked out to strike for their rights as coal miners. "Our need is for the retirement, welfare, and hospitalization benefits which UMW can give us," one striking miner said of the situation. "The League is controlled by the company. They've never had an open meeting to discuss our problems with us. After the election of the last committee we asked to join District 17. They refused to hear our arguments, so we came out." The miners also feared the loss of pensions when the company would eventually close in the future, as well as the loss of pension payments to widows and children of miners. One miner claimed Widen miners paid a total of $\$ 8.40$ a month in dues for welfare, retirement, hospital, and insurance fees, while UMWA miners paid only $\$ 4.00$ a month for all of these same benefits. ${ }^{11}$

Set up around the entrance to the mines in town, the picket line soon turned violent. On October 1, in an effort to turn away carloads of company and non-striking miners, strikers overturned a car carrying company guards. Striking men claimed they had tried to persuade the men to join the strike, but when the guards "came up with guns and clubs...well, we saw red. They refuse to give us a hearing and we are not going back to work." Four pistols and two high-powered rifles were found in the car. Another car had its windows broken by rocks and one of the company guards had to be hospitalized with a broken collarbone. ${ }^{12}$

Well into the second month of the strike, the picket line continued to alter work operations at the Rich Run mine. By October, the workforce of ELRICO had dwindled

\footnotetext{
${ }^{10}$ Ibid, 84; "News From Widen Coal Mine," Widen News, 24 September 1952.

${ }^{11}$ Dent, 3 October 1952; Resident of Harrison, "Readers Forum," Clay County Free Press, 27 November 1952.

${ }^{12}$ Ibid, 11; “350 Employees on Strike at Widen,” 2 October 1952.
} 
to 150 men, compared with the normal workforce of 700 . Non-striking miners did not want to face the risk involved in attempting to enter the mines and work. One miner stated that, "I'm fifty years old. I have a family. I've worked here for twenty-eight years. I can't get a job everyday and I can't stand thinking I may be shot anytime. There's a lot of men like me." "13 Mine officials upheld the men's claims of fear for their physical well-being and that this fear kept them from working in the mines. "The pickets have beaten several men who tried to work.... We hear about such terrorism in Russia, but it can happen here," one company official stated of the situation. ${ }^{14}$

Still, the confusion created by the picket line did not keep all workers from going into the mines. Many miners chose to work simply because they believed in the company and the success of the League of Widen Miners. President of the League, and ELRICO employee for thirty-six years, Lanty Facemire stated the miners in Widen did not need the UMWA because the League had always given the miners what they wanted. Facemire believed the League was doing an adequate job of bargaining because Widen miners received "the best wages and [made] more time than anywhere else in the coal industry."15

Other long-time employees of ELRICO were fully prepared to risk losing the only job they had ever had in order to unionize the mines in Widen and work under UMWA contract. One miner on the picket line claimed that when he joined the line he would have been able to retire in two years with $\$ 100$ a month pension from the League of Widen Miner's fund. He would have paid twelve dollars in dues in the remaining two years of service to the company and drawn $\$ 12,000$ in ten years, but decided that he was not "going to pay that old League fifty cents a month" any longer. ${ }^{16}$

While, miners in Widen chose a side to support, the company continued to believe outsiders had stirred up all of the trouble in Widen. The company could not fathom thinking its miners would have reasons for grievances. In an editorial to the Clay Messenger, a citizen supported the company view that striking Widen miners were,

${ }^{13}$ Don Seagle, "Blasts Felled Two Spans Used by Mail Train,” Charleston Gazette, 24 October 1952.

14 “Widen Pickets Hurl Train-Stop Threats," Charleston Daily Mail, 4 October 1952.

15 "Widen League Members Active in Community Affairs-Represent Old Families," Clay Messenger, 1 September 1953.

16 "Cost of a Place on the Picket Line," Clay Messenger, 16 December 1952; “Don’t Be a Sucker," 6 January 1953. 
being prodded into continuing [the strike] by a bunch of hangers-on, from distant places, whose only intention is to keep the trouble stirred up as long as possible. Many men who swagger around on the picket line have never worked in Widen or anywhere else for the company. They seize this opportunity to settle some old grudge...or for some other reason unknown only to themselves. ${ }^{17}$

Anticipating rising tensions in the town, state police were dispatched to Widen to keep peace. They ordered the pickets to let all traffic pass, but striking men refused to let cars pass unless each had been searched. The tensions created by the picket line, the company guards, and the presence of the state police eventually caused another violent outbreak. On October 4, striking men stopped a train on the Buffalo Creek and Gauley Railroad, assaulted workmen and company guards, and then took three other company men to Widen. Corporal T.S. Myers reported the striking men were holding the company men when he arrived in Widen around 5:30 a.m., at which time the company men were released, apparently unharmed. A spokesman for the company responded to the incident claiming the striking men had launched a "program of terrorism and fear...to intimidate miners who want to keep on working." To combat this "terrorism," the company began stationing non-striking employees on company property and around the tipple to protect equipment, particularly the seven electrical substations valued at $\$ 50,000$ each. The company also took the striking men to court in response to the so-called terrorism of the striking miners. ${ }^{18}$

On October 6, Circuit Court Judge Charles A. Duffield issued an injunction against the strikers prohibiting them from "attacking, assaulting, coercing, obstructing, threatening, or intimidating" ELRICO employees who chose to return to work or any delivery trucks trying to bring supplies into Widen. Judge Duffield also instructed the pickets not to destroy property or prevent normal operations of the company. Duffield also forbade striking men from congregating on company property or preventing the flow of vehicular or pedestrian traffic in or out of Widen using the threat of physical harm. As a result of the injunction, the picket line moved outside of town, off company property, to

\footnotetext{
17 "Who Are the Losers?," Clay Messenger, 14 October 1952.

${ }^{18}$ Wallace E. Knight, "Two Mine Employees Beaten in New Widen Strike Violence, "Charleston Gazette, 4 October 1953.
} 
the mouth of the only road leading into Widen, which gave the striking men exclusive control over vehicular traffic in and out of town. ${ }^{19}$

On October 11, unknown perpetrators shot high-tension electric lines, eliminating power into the town of Widen. In response to the growing complaints from Widen citizens of the lack of law enforcement in the town, Major R.W. Boyles of the state police asserted that his officers had no authority to interfere with "civil issues" in Widen because most incidents had taken place on private property. Boyles did assure Widen citizens that state police troopers were in "reinforced numbers" surrounding the area and that state police headquarters were "keeping a careful watch on the potentially explosive situation." Despite their claim of lack of authority in the town, state police started an investigation into the power line shootings and began arresting men for violations of the court injunction, as well as violations of civil rights of Widen citizens. ${ }^{20}$

On October 14, state police charged eleven striking men with violation of the Red Men's Act for the assaults on the railroad workers ten days earlier. A West Virginia state statute enacted in 1882, violation of the Red Men's Act assumes a conspiracy between two or more persons to do bodily harm or inflict punishment to other persons or to destroy private property. The Clay County Circuit Court released the men on $\$ 500$ bond each. The circuit court also cited twelve strikers for violation of the injunction granted to ELRICO and set court dates for their trials. The court based the violation on the fact that these men "congregated in large numbers and stopped automobiles wishing to enter Widen.",21

The strike violence increased in scale when dynamite destroyed two bridges on the Buffalo Creek and Gauley Railroad on October 23. The blasts not only broke state law, but were also federal offences because the trains running on the BC\&G carried mail. The blasts destroyed the Sand Fork Bridge, spanning 135 feet, and blew in half the 85 feet long Robinson Fork Bridge. As violence became more prevalent in the town, Widen citizens feared what would happen next. "Just how long these boys around here are

19 “Judge Duffield Grants Injunction,” Clay Messenger, 7 October 1952; “Clay Coalmen Get Injunction," Charleston Gazette, 6 October 1952.

20 "Partial Blackout Hits Widen Area," Charleston Gazette, 11 October 1952.

21 "11 Pickets at Widen Held for Conspiracy," Charleston Gazette, 15 October 1952; Edward M. Steel, Jr., ed., The Court-Martial of Mother Jones (Lexington: University Press of Kentucky, 1995), 26, $100-101$. 
going to take this sort of thing, I don't know. I am afraid one of these days the tension is going to snap and then there is going to be hell to pay." 22

Concerned citizens formed the Widen Citizens' Association for Law and Order (WCALO), and sent a wire to Governor Okey Patteson urging him to attend to the violent situation emerging in Widen.

There is nothing under control here except those of us who are living in town. Cars have been overturned; drivers have been refused the right to reach the state highway; cars have been stopped and searched; law-abiding citizens have been subject to all sorts of abuses and threats; telephone lines and electric power lines have been destroyed; railroad bridges demolished and a passenger train hit by rifle bullets....The people of Widen have been very patient and under strict self-control waiting for the proper authorities to take appropriate stops for protecting private citizens. We ask you Governor, how long must we wait? ${ }^{23}$

The Clay Messenger relayed stories of mob rule, intimidation, and starvation in Widen and pleaded with the governor to bring aid to the situation. The newspaper told of a group of women from Widen who asked the governor to not force them to "live in fear and be forced to live under the dictates of the mob... [refusing] to let milk be unloaded" in order to feed children in Widen. The Messenger also reported of a special meeting of the common council of the Town of Clay on October 10, in which the council condemned the conditions in Widen and called upon the governor to "exert the full powers vested in him to restore peace and order, to protect our people and to enforce the law... [in order] to end this state of lawlessness." Widen citizens also called for the removal of Clay County Prosecuting Attorney, Dana Eakle, for neglecting his duty to enforce the law in the county. ${ }^{24}$

In response to the call by the Clay Mesenger and WCALO for the impeachment of Prosecuting Attorney Eakle, the Clay County Free Press published an article accusing the Widen citizens of trying to use the strike situation in the town as political leverage to elect a Republican into office. The newspaper supported Eakle, claiming he had always proven a highly respected and efficient public official. The Free Press went on to accuse

${ }^{22}$ Seagle, 23 October 1952.

23 "Widen Dynamiting Story Unverified," Charleston Gazette, 24 October 1952.

24 “Can We Be Free If We Live in Mortal Fear?," Clay Messenger, 14 October 1952; “Clay Town Council Asks for Law Enforcement," 14 October 1952; "Widen Law Enforcement League Petitions Prosecutor's Removal," 28 October 1952. 
ELRICO and its "stooges" of treating its employees with "as much respect as Stalin would treat some of his slaves." The newspaper also stated the problems in Widen would continue as long as ELRICO continued to use "editors like the editor of the Clay Messenger for [its] public relations. ${ }^{, 25}$

As predicted, more incidents of picket violence continued throughout October and into November. Instances of rocks thrown and gunshots fired at passing cars by striking miners became a common occurrence. Clay County courts cited eights picketing miners for violation of the non-violence injunction and sentenced two ELRICO employees to six months of jailing, fining each $\$ 50$ dollars for brandishing guns. The court released the two on bond without serving jail time. By the sixth week of the strike, the State Labor Commission's Office requested ELRICO to conduct an election to establish the bargaining representative for its miners. The UMWA immediately agreed to such an election. Hoping to bring an end to the strike, Commissioner Charles Sattler contacted Bradley and offered state assistance to protect ballots for the election. ${ }^{26}$

Under the National Labor Relations Act, miners at Widen should have been able to call a National Labor Relations Board election to determine their collective bargaining representative. John L. Lewis called for and received a NLRB election in 1944, but the Board denied his request in 1952 because he refused to take the non-Communist oath required by the Taft-Hartley Act. Therefore, the UMWA did not have legal right to call for a NLRB election, rendering all formal NLRB procedures null and void in the situation at Widen. ${ }^{27}$

Sattler's request resulted in non-compliance by the company. Bradley refused the commissioner's offer to supervise an election, asserting his company had a contract with the League of Widen Miners that was set to run until 1953. Therefore, Bradley believed it was impossible for ELRICO to even consider bargaining with another union. "The

${ }^{25}$ Let's Keep Politics Out of It," Editorial, Clay County Free Press, 30 October 1952; "Widen: Story of Divided Families," Charleston Gazette, 23 November 1952. Eakle lost the election for the Prosecuting Attorney position a few weeks later by less than 20 votes.

26 "Widen Tie-Up Enters 6 ${ }^{\text {th }}$ Week," Charleston Gazette, 28 October 1952.

27 "Warfare in the Coal Fields," Clay Messenger, 25 August 1953; Fulmer, 12-15; Millis and Brown, 545. Hoping to stimulate unions to get rid of Communists, the non-Communist section of the TaftHartley Act, Section 9(h), required affidavits disclaiming Communist membership for representation cases regarding "union-shop elections and to all charges filed by unions." Therefore, access to the National Labor Relations Board processes was limited to unions that filed the required non-Communist affidavit. See pages 545-560 of Mills and Brown for more information on Section 9(h) of the Taft-Hartley Act. 
League of Widen Miners has been certified by the National Labor Relations Board as a bargaining agent for our men and we have a contract with it. I abide by my contracts.,28 Bradley's statement of loyalty to his contracts seemed merely a weak excuse not to hold an election, which the striking miners believed they would have won. "Bradley wouldn't do it because he knew we would beat him. There are 610 men eligible to vote and at least 500 of us favor joining the union." 29 J.G. Bradley responded to the miner's accusations by claiming that allowing a vote in Widen "would require us [ELRICO] to violate the labor laws of the United States and to deal with a lawless group of persons who have flaunted a lawful order of the circuit courts of Clay County. Acceptance of [the] proposal would involve disloyalty to hundreds of loyal employees." ${ }^{30}$

As frustrations rose in the town, violence again erupted in November. Dynamite blasts destroyed a power substation on November 3 , causing $\$ 35,000$ in damages. Company officials reported a partial loss of power that would slow operations that day, but stated it would not shut down the mines. Striking miners took no responsibility for the blasts and claimed the company had something to do with the destruction of its own property. The facts substantiated the miners' claims because company guards had been stationed twenty-four hours a day around the power substations since October, but on this occasion, no guards were near the substation at the time of the blast. ${ }^{31}$

The problems in Widen soon got the attention of the state government. As a response to the pleas by concerned Widen citizens, Governor Okey Patteson assured them that he had "already taken necessary steps through the Department of Public Safety for additional protection for that area." ${ }^{32}$ The governor dispatched more state troopers into the area and instructed them to stay longer hours at the picket line to keep peace. Governor Patteson's response did not satisfy the citizens of Widen or ELRICO. Mrs. D.F. McMillion sent a telegram to Patteson stating:

\footnotetext{
28 "Widen Coal Firm Spurns Ballot Bid," Charleston Gazette, 31 October 1952.

29 “Shots Rip Widen Picket's Car; 2 Sentence to Jail," Charleston Gazette, 31 October 1952.

${ }^{30}$ Ibid.

31 “\$35,000 Installation Destroyed by Blast," Charleston Gazette, 4 November 1952.

32 "Patteson Vows to Add Police in Widen Area," Charleston Gazette, 10 November 1952.
} 
Until that time it is made safe for all men and women to travel our highways, unmolested, without vile epithets being hurled at them, as well as rocks, clubs, and bullets, I shall have to remain skeptical of what you say regardless of how many men you may send to the top of Widen Hill. ${ }^{33}$

In attempts to keep law and order in his town, Bradley organized his own police force made up of non-striking miners to investigate violent events in Widen that state police refused to investigate. Clay County Sheriff Howard Wilson deputized thirteen men for the Widen force who were led by former Charleston police chief, Charles Ray. ${ }^{34}$

A grand jury of the United States District Court in Huntington heard evidence against striking men on November 12, regarding an incident occurring on October 22. Reportedly, the picket line surrounded two probation officers attempting to enter Widen to check on a man that had broken his probation. The picket line eventually let the men pass, but warned they may be shot at while in town. The officers reported the incident to federal judge Ben Moore who stated that intimidation and threats on the part of the striking men would not be tolerated. Moore suggested the officers report the incident to District Attorney A. Garnett Thompson, which the men did promptly. Thompson responded by launching an investigation into the event, as well as investigations into charges of interstate automobile theft, sending of obscene literature through the mail, forgery of government checks, and post office robbery all of which occurred in the Widen area during the strike. ${ }^{35}$

Governor Patteson once again called on the state police for better enforcement of the law in the Widen area. He also requested "every able-bodied citizen" in the area to come to the aid of law enforcement, but urged citizens to impartially enforce the laws and not take sides in the industrial conflict. Patteson warned that he would enlist the aid of the Clay County police force as well as the National Guard to restore law and order if necessary. The governor also named Charles Sattler head of a three-man committee to make a "thorough and complete" investigation of the situation in Widen. Patteson requested William Blizzard and J.G. Bradley be ex-officio members of the committee. Blizzard accepted and Bradley declined stating that the "Governor should worry about

\footnotetext{
${ }^{33}$ Ibid.

34 "Ray Commands Special Guards on Widen Duty," Charleston Gazette, 12 November 1952.

35 "U.S. Violations Laid to Strikers of Widen Firm," Charleston Gazette, 13 November 1952.
} 
enforcing the laws of the state and not interfering in private affairs.... I've no labor dispute at my mines. My men have worked right through this thing." 36

Due to the increased enforcement of laws on the part of the state police, Widen citizens, and Bradley's police force, things began to calm in Widen and more and more men went back to work. The company set up a screening committee of "loyal" workers, which determined if a miner could return to work at the Rich Run mine as an ELRICO employee. Bradley felt "only those who were cited for court action should be discharged [from working for ELRICO]. But it would be an insult to loyal workers if we took back the very men who humiliated and abused them.",37

The Federal Bureau of Investigation arrived in Widen on November 17 to investigate the interference in interstate commerce as well as the dynamiting of the power substation. The probe lasted six days. Special agent-in-charge, Fred Hallford, stated that a "report on the findings had been submitted to the Washington, D.C. headquarters and will be turned over to the Department of Justice." Hallford did not comment on the results of the probe or whether the investigation discovered the culprits of the dynamitings. ${ }^{38}$

Public hearings by the Sattler committee began on November 25 at the state capital building in Charleston. The governor-appointed committee could not subpoena witnesses, so the committee sent invitations to all Widen citizens involved in the strike, as well as those citizens that had directly complained to the governor about the lawlessness in the town, to testify. ${ }^{39}$ The company attorneys initiated the proceedings by

\footnotetext{
36 "Governor Calls on Authorities to Act in Clay," Charleston Gazette, 15 November 1952; "Three Hundred Volunteer to Help Sheriff Coon Fight Crime," Clay Messenger, 17 March 1953; "Clay Citizens Association for Law and Order," 17 March 1953. In March of 1953, over 300 Clay County citizens volunteered to help Clay County Sheriff Coon stop the violence in Widen. Coon stated the volunteers would be organized into a "posse legally summoned to preserve that peace and protect lives and property in Clay County." Citizens also formed the Clay Citizens Association for Law and Order with an open membership to "anyone in the county that wishes to improve our living conditions and maintain a high standard of law and order"; "An Act of Contempt,” Editorial, Clay County Free Press, 30 April, 1953. The Free Press called the Clay Citizens Association for Law and Order a "vigilante gang" and a "farce" conceived by a few, hoping to gain individual police protection while running the striking men out of Widen for daring to "stand up for their rights." After Judge Duffield refused to grant this protection, the group responded by hurling insults and trying to discredit the State Police.

37 Don Seagle, "Strikers Deny End Impending in Widen Tie-Up," Charleston Gazette, 16 November 1952.

38 "Results of Probe at Widen Secret," Charleston Gazette, 2 December 1952.

39 "Widen Strike Hearings Set," Charleston Gazette, 20 November 1952.
} 
insisting William Blizzard and State Police Captain Burchett be removed from the committee. Company attorneys also argued for testimony to be limited to "violence and law enforcement, or the lack of law enforcement" in the town. For thirty-five minutes the committee deliberated and decided the investigation should encompass violence reported as well as the causes of the violence in Widen. The committee also decided that company attorneys could not force members off of the committee that the governor had appointed; the members in question could only remove themselves.

Upon the aforesaid announcement, Captain Burchett removed himself from the committee based on the fact that he would testify later on in the trial. Blizzard refused to remove himself, stating that he owed it to the governor to sit on the committee, a courtesy Bradley failed to confer. The courtroom audience applauded Blizzard's statement, prompting company attorneys to claim the courtroom was filled with UMWA supporters. By 11:00 a.m. company attorneys walked out of the courtroom, still protesting Blizzard's placement on the committee and claiming the scope of the investigation was too broad. ${ }^{40}$

The Widen Citizens' Association for Law and Order also criticized the committee, claiming the hearings were one-sided. The group believed the state police did not report any violence because they were not present in Widen long enough to see it. Thomas Mullins, president of WCALO, stated "of course the troopers did not witness any violence; there was no picket line in front of the detachment headquarters in Clay." The association left the courtroom after Chairman Sattler interrogated corporal Myers of the state police. Myers recalled an incident when striking miners picked up the rear of his patrol car, rendering him unable to proceed. Myers laughed at the incident, seeming only to be concerned with the damage done to his car, not the lawlessness of the picket line. ${ }^{41}$

WCALO was not the only group upset with the proceedings of the governorappointed committee. The West Virginia Chamber of Commerce denounced the investigation in a report charging that the state police made only the "most timorous efforts at law enforcement." The chamber supported the Elk River Coal and Lumber Company, stating the UMWA was attempting to "blast into submission" one of the few remaining non-union coal companies in the nation. The chamber also charged the

\footnotetext{
${ }^{40}$ John G. Morgan, "Lawyers Bolt When Blizzard Sticks to Job," Charleston Gazette, 26 November 1952.

41 “Widen Committee Held One-Sided," Charleston Gazette, 30 November 1952.
} 
committee with bias based on the fact that all the members had proven through previous doings that they were pro-labor. Finally, the chamber held the committee one-sided because only striking men had given testimonies due to the fact the company attorneys had walked out of the proceedings. ${ }^{42}$ William Blizzard responded to the group's report by stating that it was typical in the organization's efforts to "cover up law violations." Blizzard put forth his own accusations calling Bradley, "The King of Widen," and charging the chamber with "trying to protect absentee owners who have been robbing the people of West Virginia for years." 43

Back in Clay County, the November term of the circuit court saw Judge Duffield fine one picketer fifty dollars and sentence him to sixty days in jail. Duffield also continued the cases of seventeen other picketers charged with violating the non-violent injunction and lectured the striking men of the seriousness of violating the injunction. ${ }^{44}$ Despite Duffield's warnings, the violence and violations of the injunction continued into 1953.

On January 16, 1953, state police investigated two explosions that had occurred days earlier in Widen. The first explosion involved a land mine planted near the car of Gilbert Jarvis, a non-striking miner. Jarvis did not drive to work that day, but his wife received two visitors from Richwood, whose car detonated the land mines. The two women were taken to the hospital, one suffering from a broken ankle. The second explosion damaged around one hundred feet of track and a culvert of the BC\&G railroad. ${ }^{45}$ Despite the damages and lingering threat of danger, state police investigators failed to find any perpetrator of the explosions.

42 “The Widen Story," Clay Messenger, 9 December 1952; “Chamber Blasts Widen Probers," Charleston Gazette, 6 December 1952. The members of the committee who the chamber believed were: Charles J.F. Sattler (chairman), State Commissioner of Labor since 1941 and active in "union circles" for thirty years. John G. Fox, Attorney General, who as a delegate, "followed the UMWA political line in every particular, voting against management on the controversial 'Fire Boss' bill; voting in favor of regularly paying unemployment benefits to strikers...voting also for the so-called 'Anti-Injunction' bill." Curtis B. Trent, Workmen's Compensation Commissioner, who has proven himself "an undeviating adherent to the United Mine Workers political line." William Blizzard, President of the UMWA District 17. J.G. Bradley, President of ELRICO, who, according to the Chamber of Commerce, represented the "only committeeman actively identified with or arrayed on the side of management."

43 “Blizzard Returns Chambers’ Blast," Charleston Gazette, 7 December 1952.

44 "Widen Picket Fined, Sentenced to Jail," Clay Messenger, 11 November 1952.

45 "Police Probing Two Explosions in Widen Area," Charleston Gazette, 17 January 1953. 
At the beginning of 1953, Bradley made clear his thoughts on the strike in an issue of the Widen News. He believed Lewis had been "chided" into trying to unionize Widen and now that he had started, Lewis could not quit until he succeeded. Bradley also spoke of the financial cost of the strike to ELRICO. "He [Lewis] has put us to an enormous expense, and worse than that, he has destroyed our efficiency at the mines. The UMW has brought terror and commotion to the community." Bradley went on to say the company had been losing profits at a fast rate, but added that the "red ink is getting less every month. ${ }^{46}$

A grand jury under Judge Charles Duffield handed down thirty-seven indictments against striking miners in Widen on February 3. The jury reported:

[F]rom late in September until about November 20, 1952, almost a complete state of anarchy existed in that District, that during this period many law-abiding citizens were denied the natural right to work and the right to have protection for themselves and their property.

The jury went on to blame the county sheriff, the prosecuting attorney, and the state police for not enforcing the law in the Widen area. ${ }^{47}$

Amidst the turmoil, the company continued to assert that it was still in charge of operations in Widen. The League of Widen Miners held a meeting to try 156 members accused of violating the League's constitution. The League sent notices to the accused members that stated the charges against them and requested their attendance at a meeting for a chance to defend themselves against the charges. During the meeting, superintendent Gandy claimed that the Widen mines had the best safety record in West Virginia. Non-striking miners concurred with Gandy, adding that they also get paid more than UMWA miners, always had good working conditions, and management settled grievances easily. The meeting ended when members who admitted to conspiring against the League were dropped from membership. ${ }^{48}$

In March, the League of Widen Miners approved a new contract that members and the company hoped would end the strike. On March 12, league members and J.G.

\footnotetext{
46 "What the President of the Elk River Coal and Lumber Company Thinks and Has Said About the Strike at Widen," Widen News, 29 January 1953.

47 "Grand Jury Investigating 'Widen Affair' Report is Critical of Law Enforcement," Clay Messenger, 17 February 1953.

48 "League of Widen Miners Clearing Rolls of Erring Members Saturday," Clay Messenger, 17 February 1953.
} 
Bradley signed the contract, providing hospitalization at Charleston General Hospital and featuring a newly revised welfare plan. Bradley stated the new contract put the cost of coal produced in Widen at $\$ 6$ a ton, which was "too high a price," but believed that increasing production in the mines would allow him to pay wages and still continue to operate according to the new contract. The new contract did not provide an end to the strike, and the tensions and lack of policing in the area finally resulted in the death of a non-striking miner on May 7, $1953 .^{49}$

Around 4:30 a.m. a convoy of non-striking men drove past the "cook shack," the striking miners' headquarters. Shots rang out as each side fired. In the midst of the gunfire, a bullet hit non-striking miner Charles Frame in the head and killed him instantly. State police arrested thirty-seven striking men at the scene and brought thirteen others in hours later. Clay County Prosecuting Attorney James Reed believed information acquired by the state police would allow him to charge all fifty men arrested with murder if none confessed to the crime.

Many of the men held were taking a jesting attitude toward the incident.... Apparently those men don't believe that any of them will ever be prosecuted. They just don't seem to think that they will ever be tried. I can assure you that this investigation will be carried to the utmost limit, and that someone, or more than one will be prosecuted for murder of this man...the entire bunch may be prosecuted for murder. ${ }^{50}$

While waiting for the trial to begin, both sides began to tell their story, each claiming the other fired shots first. Dewey Triplett, spokesman for the arrested men, stated that he had been warned the day before by a mine guard to "clear out the women and children because we're coming to clean you out." Triplett also stated that most of the accused men were either asleep or not even in the area at the time the gunfight occurred. Those who did admit to shooting at the company men claimed they did not aim to hit anything or anyone. ${ }^{51}$

One week later, William Blizzard responded to the murder at a press conference and claimed the company guards instigated the whole incident. He believed company

\footnotetext{
49 "Contract Completed After Negotiation, Facemire Thanks Men for Cooperation," Clay Messenger, 31 March 1953.

${ }_{50}$ "Some Suspects Admit Ambush," Charleston Daily Mail, 8 May 1953.

${ }^{51}$ James A. Hill, "Dille Miner Says Company Guards Ignited Gun Battle," Charleston Gazette, 11 May 1953.
} 
guards attacked the picket line and dynamited the "cook shack" at the beginning of the week of the murder, which enraged the striking miners. The company replied that its men had acted within their rights to get the striking men off ELRICO property, but that it did not sanction the actions taken by its men. Regarding the gunfight, striking miners claimed the day before the events of May 7, company guards approached them and warned to "Remember 4 o'clock." As predicted, the shooting began at four the next morning. ${ }^{52}$

Blizzard and the jailed men also attacked the press for the persistence of the problems in Widen. The jailed men refused to speak with reporters because they believed the press was biased in favor of the company and only printed stories in favor of ELRICO during the whole strike. Striking men claimed the press never reported stories of abuse and destruction of strikers' property. The press responded to the miners' accusations by stating that it never reported those incidents because the striking men had refused to speak to them. Blizzard, also upset with the press's coverage of the strike, claimed that although the strike had been going on for seven months, "I don't remember either newspaper calling me, yet I was financing and directing the strike." Blizzard also attacked the company and company guards, blaming them for the death of Charles Frame. Blizzard believed the company's refusal to accept the will of the workers was the sole cause for the strike and the resulting violence in Widen. ${ }^{53}$

On May 13, the striking miners waived their preliminary hearing after meeting with attorneys, and judge Duffield set the case for grand jury in the June term of the circuit court. The men were released on $\$ 2,000$ bond the next day. All posted the bond themselves, but Blizzard declared that the UMWA was prepared to help them if necessary. The court set higher bonds of \$7,500 for Dennis Zirkle, Dennis Graham, Clifford Lee Pritchard, and Jennings Roscoe Bail. Attempting to prevent any further confrontations between striking miners and company guards, Duffield suggested that ELRICO keep guards only on company property. The company refused to comply. The UMWA agreed to Duffield's request for state police-assisted convoys to transport men

\footnotetext{
52 “Widen's True Story Not Told, Blizzard Informs Press Clinic," Clay County Free Press, 21 May 1953.

${ }^{53}$ Ibid. By "either newspaper" Blizzard referred to the Charleston Gazette and the Charleston Daily Mail.
} 
who wanted to continue working in the mines. ${ }^{54}$ Blizzard stated he complied with Duffield's suggestion of a police-assisted convoy, but did not believe it was needed because,

we have not started any violence and we do not intend to start any. Our pickets have conducted themselves peacefully and they have been attacked by company guards... We do not intend to trespass on the company's property, but will picket... where we are free to do so under the assurance that we will be protected by the court and by the governor of this state. ${ }^{55}$

Bradley's assistant, Harry L. Gandy also issued a statement regarding the company's refusal to comply with judge Duffield's request. Gandy stated that the company would not refuse any aid by the state police, but merely refused to meet with Blizzard or any other UMWA official because of the crimes these persons had committed against the company and its employees over the duration of the strike. "Under such circumstances, we do not propose to sit down and parley with any man who openly boasts that he is both directing and financing the strike which resulted in these crimes." Gandy also stated the company refused to comply with any agreement that would reestablish the picket line at the top of Widen Hill and the lawlessness it promoted. ${ }^{56}$

Back in Widen, state police arrested three men charged with shooting the hightension wires that caused a blackout in October of 1952. Clifford Pritchard, Chelsie Bailes, and Harry Herbert Johnson all confessed to the charges and Circuit Judge Charles F. Gavin sentenced the trio to twelve months in jail and fined each $\$ 5,000 .^{57}$

By May 21, striking miners were released from jail and reinstated the picket line of fifty to one hundred men strong at the top of Widen Hill. As the months passed by, the enthusiasm slowly waned and numbers at the picket line eventually dwindled to only thirty-five. Many miners began to look for other ways to support their families. The non-striking miners who had not returned to work in the mines due to intimidation on the

\footnotetext{
54 “"Murder Bond of Four Men Fixed Higher," Charleston Daily Mail, 14 May 1953; “Widen Miners Furnish Bond, Are Released," Charleston Gazette, 15 May 1953.

${ }^{55}$ William Blizzard, "Rival Camps Firm on Widen Picketing: Union Statement," Charleston Gazette, 17 May 1953.

${ }^{56}$ Harry L. Gandy, "Rival Camps Firm on Widen Picketing: Company Statement," Charleston Gazette, 17 May 1953.

${ }^{57}$ Three Confess to Destroying Power Line, Get Sentence," Clay Messenger, 26 May 1953. The three men served time in a Nicholas County jail because the incident took place just over the Clay County line.
} 
part of the picket line filed for unemployment. The Board of Review of West Virginia Department of Employment Security's decision stated that each claimant would have to show he had tried to find employment elsewhere during the time he was kept from work at Elk River Coal and Lumber Company. The company claimed many men "voluntarily quit their employment without good cause," and therefore should not be compensated for their loss of work. The review board ruled that the strike would not be considered a labor dispute, but a "contention between factions of a union for control and not with the employer." 58

The cases of the eleven men charged with violating the Red Men's Act by assaulting company guards in October 1952 began on June 9. First to go on trial, Virgil Nelson testified that he was acting in self-defense when he struck a deputy sheriff. Nelson said the officer struck the first blow resulting in him hitting the deputy with his fist. The other eleven testified they were only at the scene to relieve other striking miners and to attempt to persuade non-striking miners to join the UMWA. The trial ended with a hung jury after four and a half hours of deliberation. ${ }^{59}$ As a result of the hung jury, judge Duffield postponed the next trial for Nelson as well as the other eleven until the October term of the circuit court. Duffield dismissed the jury set to hear argument for the next case against Jack Lanham, and ordered a jury made up of Braxton County citizens to hear the trials in October. Duffield believed "there were not enough unbiased Clay County residents to form juries for all 11 of the conspiracy defendants. $" 60$

On June 15, 1953, Judge Duffield continued Jennings Roscoe Bail and Dennis Graham's trials to a special term to be held in July. As a result of his previous jury problems during Nelson's conspiracy trial, Judge Duffield also ruled that qualified jurors could not conveniently be found in Clay County, therefore he would draw potential jurors from Braxton County. The defendants objected on several grounds, but Duffield overruled the objections and set Bail to stand trial on July $27 .^{61}$

\footnotetext{
58 "Board of Review Gives Decision in Elk River Unemployment Cases," Clay Messenger, 7 July 1953.

59 “Nelson Trial Ends With Hung Jury, Lanham Case Next," Clay County Free Press, 11 June 1953.

60 “Clay County Jury Refused to Convict Striking Miners; Braxton Men Called," Clay County Free Press, 18 June 1953.

${ }^{61}$ Law Orders, Clay County Circuit Court, Clay, West Virginia, 15 June 1953.
} 
At the trial in July, UMWA defense lawyers, Hillis Townsend, D.L. Salisbury, and Earl L. Eakle tried to prove that company guards wanted to push the strikers out of their meeting place at the "cook shack." They also set out to confirm that the company guards had warned striking miners of an upcoming ambush, and "the death of Frame was a direct part of the chain of events which started two or three days before the shooting." Judge Duffield admitted after the murder that a group of striking men had met with him a few days before the incident to make him aware that company guards had threatened them. Duffield stated that he reported the threats to a company official and asked him to do all that was necessary to prevent the trouble, but he admitted that he was not successful in his endeavor to prevent the impending violence. Corporal C.G. McClain of the state police also testified that two men visited him the day before the shootout. McClain stated that he instructed the men to take up the matter with the Clay County police. ${ }^{63}$ William Blizzard also testified that he had been made aware of the impending violence in Widen when several striking men came to his office in Charleston and asked for protection from the threats company men had made towards them. Blizzard said that he relayed the threats to Governor William Marland and that Marland called the superintendent of the state police, Colonel R.W. Boyles, to inform him of the imminent problem in Widen. ${ }^{64}$

Bail took the stand on July 28 and admitted in testimony that he fired several times at the convoy, but he only shot back in self-defense. Prosecution attorneys read excerpts from a signed statement that they claimed Bail made to the state police upon being arrested on May 7. In the statement, Bail admitted he "shot at two light colored cars, aiming at the radiators and engines." Bail denied parts of the statement claiming that police officers forced him to sign the confession. ${ }^{65}$

The jury came to a verdict on August 7 and charged Bail with second-degree murder. Bail's attorneys immediately made a motion to set aside the sentence, claiming

\footnotetext{
62 "Widen Miners Trial Continues, Defense Claims Convoy Started Fight; Marland, Blizzard Called," Clay County Free Press, 30 July 1953.

${ }^{63}$ Charles R. Lewis, "UMW Chiefs Okay Convoy Plan at Widen," Charleston Gazette, 16 May 1953; "Widen Miners Trial Continues, Defense Claims Convoy Started Fight; Marland, Blizzard Called," Clay County Free Press, 30 July 1953.

64 "Defense Attorney's Rest Case Wed., Widen Murder Trial May End Today," Clay County Free Press, 6 August 1953.

65 "Bail Trial May Go To Jury Friday Morning," Clay Messenger, 4 August 1953.
} 
it "contrary to law and evidence." Townsend stated that Bail had been the "unfortunate victim of a situation he did not create." his appeal to the court. A few weeks after the conviction, defense lawyers insisted that judge Duffield "did not make a thorough effort to exhaust all sources for jury personnel in Clay County." Therefore, they believed that Bail's sentencing should be overturned. ${ }^{67}$

Defense lawyers declared that drawing a jury from outside Clay County infringed upon Bail's rights, and planned an appeal to the State Supreme Court. Despite the appeal from Bail's lawyers, judge Duffield upheld the conviction and sentenced him to five to eighteen years in the state penitentiary on August 21. Duffield upheld his decision stating it was his opinion that a fair and unprejudiced jury could not have been found in Clay County. Prosecuting attorney Reed also supported Duffield's decision by referring to a statute that allows the court to obtain a jury from another county "when the judge believes it will not be conveniently possible to draw one from the county in which the trial is being held. ${ }^{, 68}$

Duffield granted Bail a stay of execution to allow for his appeals to the State Supreme Court and set Dennis Graham's murder trail for the October docket of the Clay County Circuit Court. The court postponed Clifford Pritchard's trial because he was serving time in the Nicholas County jail for destruction of high-tension power lines in October $1952 .{ }^{69}$

In September, the West Virginia Chamber of Commerce officially adopted a resolution blaming the United Mine Workers of America for the destruction of property, cases of assault, the murder of Charles Frame, and the deprivation of a man's right to work all occurring in Widen during the strike. The resolution also criticized the lack of law enforcement on the part of federal officials in the town, commending state and county officials who "are now making a sincere effort to enforce the laws of our state."

66 "Braxton County Jury Convicts Bail, Attorneys Ask Sentence Be Set Aside," Clay County Free Press, 13 August 1953.

67 “Bail Defense Flays ‘Outside’ Jury Use,” Charleston Daily Mail, 21 August 1953.

68 "Picket Loses, Draws Term," Charleston Daily Mail, 22 August 1953.

69 "Bail Draws 5-18 Years," Charleston Gazette, 22 August 1953. 
The chamber also criticized the UMWA for bringing negative publicity on the state of West Virginia. ${ }^{70}$

On October 20, a United States federal court handed down thirty-seven indictments against striking miners for violation of civil rights of fifty-eight people. A. Garnett Thompson, U.S. attorney for southern West Virginia district, said that the "decision to prosecute civil rights cases is made by the Justice Department in Washington." "The indictments charged the thirty-seven with "joining forces to 'unlawfully injure, oppress, threaten and intimidate' others in an effort to make them join a labor union." The cases were transferred to Charleston, under Federal Judge Ben Moore's jurisdiction, from Huntington because Widen falls in the Charleston federal court district. $^{72}$ Federal judge Moore postponed the trial of the thirty-seven charged with violation of civil rights from November 16 to February 23, 1954. Moore moved the trial date to allow both prosecution and defense lawyers ample time to build their cases and said that he would hear their arguments on November $13 .^{73}$

The Clay County Circuit Court opened its October term with the second Virgil Nelson trial for violation of the Red Men's Act. Despite having a jury from Braxton County, the case once again ended with a hung jury. The October term also saw judge Duffield continue the case of Dennis Graham to the January term of the circuit court. ${ }^{74}$

At the beginning of December, William Blizzard stated the UMWA was still feeding 145 striking miners and their families in Widen, but noted that over 100 other miners had left the Widen area to search for jobs elsewhere. The UMWA leader claimed ELRICO was losing "at least one dollar on every ton of coal it sells. For 1953, that will mean something like six hundred thousand dollars. They're giving away their capita and their assets without a red copper in return, and I don't imagine they'll go on doing that for more than another year or so." Yet, the company continued its fight against the UMWA

70 “West Virginia Chamber of Commerce Blasts UMW Union,” Clay Messenger, 8 September 1953.

71 "U.S. to Seek Widen Writs," Charleston Daily Mail, 20 October 1953.

72 "Widen Case Shifted Here," Charleston Daily Mail, 23 October 1953.

73 "Validity of Conspiracy Indictments May Be Challenged Attorneys Said," Clay County Free Press, 5 November 1953.

74 “Second Nelson Jury Disagree on Verdict," Clay Messenger, 20 October 1953. 
and eventually drove the union out of commission, with a combined loss for both sides estimated at $\$ 2$ million dollars. ${ }^{75}$

Christmas Eve 1953 marked the official end to the strike at Widen. William Blizzard abandoned the campaign "as a lost cause," and striking miners withdrew from their position along the top of Widen Hill. Darrell Douglas, a striking miner said of the situation:

[We] were getting nowhere.... We don't like to admit defeat, but we knew we were beaten. It had been pretty costly to us, since we weren't getting anything out of it, so we decided to ask Mr. Blizzard if we could call it off. It looked like a lost cause. We still think we were right and the company was wrong, but our men were tired of staying on the picket line. Morale was low among the pickets. ${ }^{76}$

The men unanimously decided to leave the picket line and try to find work.. Douglas stated that the men would go back to work for the Elk River Coal and Lumber Company if it would allow them, but it seemed very unlikely the company would agree to such terms. ${ }^{77}$ Blizzard exclaimed his pride in the bravery and stamina of the striking men: "I admire their courage. They had plenty of it. They stayed with it a long time. They felt that it was a just cause. So do I."78

The strike cost both sides heavily. It is estimated that Bradley's Elk River Coal and Lumber Company lost nearly one million dollars. The UMWA loss is estimated at $\$ 100,000$, most of which was the cost of providing supplies to the striking miners for fifteen months; the grocery bill alone was estimated at $\$ 2,000$ to $\$ 3,000$ a week. ${ }^{79}$ In regards to the strike, Bradley spoke of who really took the brunt of the punishment: the men who stayed loyal to the company. "I found men in Clay County... who would stand up with me...they took the punishment-I only lost a million and a quarter dollars."

\footnotetext{
${ }^{75}$ Thompson, 19.

76 “A Battle John Lewis Lost," U.S. News \& World Report, 29 January 1954 from Goldenseal 3, no.1 (January-March 1977): 11.

77 “'Blizzard Abandons Widen Strike Monday as 'Lost Cause.' Pickets Fade Away Sunday Because of 'Weakened Morale,"” Clay Messenger, 29 December 1953.

78 "Strike Against Elk River Coal and Lumber Company Called Off," Clay County Free Press, 31 December 1953.

79 "A Battle John Lewis Lost," 11.

80 “Bradley Highly Acclaimed by Bankers," Widen News, 25 September 1954.
} 


\section{Chapter 5 \\ Old Age Sets In: The Decline of Widen}

After fifteen months of struggling with the company, the striking miners finally gave up their fight to bring the United Mine Workers of America to Widen. But the effects of the strike were still being felt in the town as striking miners accused of violent acts, as well as the violations of court orders and the civil rights of other Widen citizens, awaited trials at the Clay County Circuit Court and the United States Federal Court in Huntington.

Thirty-five of the thirty-seven indicted for civil rights violations had posted bond and were released by the beginning of January 1954. One of the accused was in the army and the other had moved to Ohio and could not be located. Lawyers were to present their arguments to quash the indictments during a federal court term beginning January 19, in Bluefield, but defense attorneys did not give arguments to the federal court judge until March 15. ${ }^{1}$ At the hearing, Judge Harry E. Watkins stated, "[T]his motion presents some very important questions that have never been adjudicated by courts of this land. It demands extensive study and consideration, and I plan to give it that." UMWA attorney, Mose E. Boiarsky, challenged the indictments on eleven counts, questioning whether violations of civil rights should be upheld by the National Labor Relations Board under provisions of the Taft-Hartley Act or by criminal prosecution.

Title I, Section 12 amendment to the Taft-Hartley Act addresses "unlawful concerted activities." Under the amendment, unions may not engage in activities that "interfere with the movement of employees or the public into and out of the employers' property." 2 The amendment also gives the right to any person injured by unlawful activity by union members to sue those responsible for the injury to their person or property. Conviction brought a fine of $\$ 5,000$, one year in prison, or both. ${ }^{3}$ Thus, the state argued that the citizens of Widen who felt that their right to peacefully move in and out of the town had been violated, had the right to sue for damages.

\footnotetext{
1 “Widen Cases Set Jan. 19,” Charleston Daily Mail, 5 January 1954.

${ }^{2}$ William B. Gould, A Primer on American Labor Law, $2^{\text {nd }}$ ed. (Cambridge \& London: MIT Press, 1986), 52.

${ }^{3}$ Legislative History of the Labor Management Relations Act, 1947, printed for the Subcommittee on Labor of the Committee on Labor and Public Welfare, United States Senate (Washington D.C.: U.S. Government Printing Office, 1974), 335 \& 264.
} 
Defense lawyer Boiarsky believed that the Taft-Hartley civil rights code was "vague and ambiguous" and questioned if the alleged conspiracy even fell under labormanagement laws. Boiarsky argued that "the right to join a union is an inalienable right that can't be granted by Congress or secured by federal law," therefore there should be no criminal prosecution against that right. Boiarsky also argued that the striking men did not prevent the "victims" from contacting local law enforcement or the NLRB to complain about the infringements upon their rights. William T. Lively, prosecution attorney, argued that the cases were purely criminal, and should fall under labor-management laws. Lively declared that ELRICO was involved in interstate commerce and, therefore, Congress had an obligation to secure the rights of the people whose livelihood was directly connected with the company. Judge Watkins assured both sides that he would give the case "all the time it demands."

In February, judge Duffield scheduled a special April term of the circuit court to deal with the eleven men charged with violating the Red Men's Act, as well as the Graham, Pritchard, and Zirkle cases pending for the murder of Charles Frame. But, due to conflict with the federal court term in April, Duffield cancelled the special term on April 6. The judge said he cancelled the session because several of the cases involved people already set to be tried in federal court in April. ${ }^{5}$

During the second week of April, 1954, Judge Harry E. Watkins dismissed the indictments against the thirty-seven accused of violation of civil rights of fifty-eight people in the Widen area. Watkins stated that the indictments did not constitute a federal offence and should have been dealt with at the local level. He upheld that unfair labor practices under the Taft-Hartley Act only apply to an employer, a union, or its agents. "What the government is trying to do is to prosecute an unfair labor practice as a federal criminal conspiracy, though what is charged does not constitute such unfair practice. The remedy is prompt and vigorous prosecution in the state courts," Watkins stated. ${ }^{6}$ The

\footnotetext{
4 "Dismissal Asked in Widen Civil Rights Case, Trial Set for Apr. 12 in Charleston," Clay Messenger, 16 March 1954.

5 “Judge Duffield Drops Special Term Circuit Court," Clay Messenger, 6 April 1954.

6 "Watkins Says No Violations of U.S. Law in Widen Cases," Clay Messenger, 13 April 1954; "Indictments Against Strikers Are Dismissed By Federal Judge," Clay County Free Press, 15 April 1954.
} 
solicitor general's office announced on June 7 that no appeal would be made against judge Watkins' dismissal of the thirty-seven indictments for violation of civil rights. ${ }^{7}$

Almost a year to the date of the murder of Charles Frame, Jennings Roscoe Bail appealed to the West Virginia Supreme Court to overturn his conviction of second-degree murder. The written petition cited seventeen errors by the Clay County Circuit Court and specifically charged that judge Duffield had violated federal and state constitutions by drawing a jury from outside of Clay County. The petition upheld that "a good, fair, and impartial jury could have been obtained from the lists of qualified and eligible voters" in Clay County. The petition also pointed out that only 110 names were drawn for a potential jury when there were 3,757 eligible jurors in the county. ${ }^{8}$

At the June term of the Clay County Circuit Court, Judge Duffield continued the remaining twenty Widen cases until the October 1954 term on a request from Mose E. Boiarsky on behalf of D.L. Salisbury, defense council, who was ill. ${ }^{9}$

The first week of January, 1955, saw the West Virginia Supreme Court delay hearing arguments to dismiss the conviction of Jennings Roscoe Bail. J.W. Maxwell, attorney for the Elk River Coal and Lumber Company, informed the court that three other cases involving the murder of Charles Frame were still pending in the Clay County Circuit Court, thus he believed that the filing of additional briefs would be a "desirable step to the 'threshing out' of certain questions before the other trials began." Mose Boiarsky, defense counsel, had no objections to the filing of an additional brief but he objected to the cooperation of the state attorney general's office and the Clay County prosecutor in filing the brief. The court ruled that it would be under its discretion whether prosecutor Reed would be permitted to aid the state attorney general in the case. $^{10}$

Bail's case came before the state supreme court on January 26, 1955. Defense attorneys argued that judge Duffield did not exhaust the efforts necessary to find an impartial jury in Clay County. The attorneys maintained that state law allows courts to draw a jury from another county only when it "clearly appears" that a competent jury

\footnotetext{
7 “U.S. Accepts Widen Ruling," Charleston Gazette, 8 June 1954.

8 "Court Asked to Kill Verdict in Roscoe Bail Case," Clay County Free Press, 6 May 1954.

9 "Picket Cases Deferred to October Court Term," Clay Messenger, 15 June 1954.

10 “Court Delays Bail Hearing," Clay County Free Press, 20 January 1955.
} 
cannot be drawn from the county in which the incident took place. Defense counsel again pointed out that judge Duffield only questioned 110 out of a possible 3,767 jurors, which did not make it clear that an impartial jury could not be found in Clay County. Bail's attorneys also argued that his statement presented during the trial should not have been allowed as evidence. Bail claimed that state police officers forced him to sign the statement, but the state argued that Bail admitted to signing the statement voluntarily while on the witness stand.

State attorneys justified Duffield's juror decision by explaining that his experience with drawing juries for previous trials regarding incidents in Widen allowed him to be certain that impartial jurors could not be found in Clay County. The state argued that judge Duffield called jurors from Braxton County in order for Bail to have a "fair and impartial trial," because he believed "practically every Clay County resident had either a direct or indirect interest in the strike." "11 After hearing arguments from both sides, the state supreme court reversed Bail's conviction on March 15, 1955 on the grounds that the state failed to clearly show that no qualified jury could be found in Clay County. ${ }^{12}$

Judge Duffield continued Bail's second trial at the June term of the Clay County Circuit Court. D.L. Salisbury, Bail's attorney, asked for the continuance because several of the witnesses he subpoenaed could not attend the June session. Salisbury stated that of the eighty witnesses he subpoenaed, only twenty-nine showed up at the courthouse. The state had no objections to the continuance. The fact that only twenty-nine out of eighty witnesses showed up for the trial clearly illustrates that the miners that were involved in the strike at Widen were beginning to move out of the area hoping to find other jobs. The Clay County Free Press pointed out important changes in the court composition since the first trial occurred twenty-three months prior. The doctor who examined Charles Frame's body and previously testified to the cause of death had moved to California. The state police chemist who did most of the lab work for the case had moved to Montana. Finally, because ELRICO refused to rehire striking miners, most of them had moved out

\footnotetext{
11 “Attorney Charges Unfair Jury Trial; Case Now Before Supreme Court," Clay County Free Press, 27 January 1955.

12 "Bail Trial Continued Until February Term of Court," Clay County Free Press, 13 October 1955.
} 
of the area, even out of the state, to find work. The loss of these eyewitnesses changed the make-up of the second trial considerably. ${ }^{13}$

Continuances for Bail, Graham, Zirkle, and Pritchard's murder trials, the cases of the eleven charged with violation of the Red Men's Act, and many more misdemeanor cases involving the Elk River Coal and Lumber Company against striking miners continued to be granted by judge Duffield until April 1, 1959, when all cases pending on the Clay County Circuit Court docket dealing with the strike in Widen were dropped by the court. The court also ordered the Clay County Sheriff to give back each firearm confiscated on May 7, 1953, to the rightful owner of that weapon. ${ }^{14}$

After the events of the strike ended, ELRICO tried to return to normal operations. In 1954, the Elk River Coal and Lumber Company employed 525 men in its mine who worked three-day shifts. The mines operated as normal until 1958, when on November 28, J.G. Bradley sold his company to the Clinchfield Coal Company, a subsidiary of the Pittston Coal Company, for $\$ 5$ million dollars. ${ }^{15}$ In a letter published by the Clay Messenger, Bradley discussed his reasons for selling his stock and his hopes for the future of Widen miners:

I have done everything I know how to make sure that you will have as steady work as anybody in the industry, and I want you to realize that this is the most important thing in life to you and your children. The new owners, I believe, will be considerate of your interests and pleasant people to work for.

Bradley went on in the letter to advise miners not to strike in the future and urged them to attend League of Widen Miners meetings and elect honest people. He ended by saying "goodbye to you as your leader, I remain your friend. I shall be one of you as long as I live." 16

Despite Bradley's promises of a bright future with the Clinchfield Coal Company, the prospect of life under new management looked very bleak to Widen miners by 1959. That year Clinchfield cut back the number of workers to 330, laying off 280 miners.

General manager Harold Beattie announced that "the layoffs were made on the basis of

\footnotetext{
13 "Case Continued Until October Term," Clay County Free Press, June 1956.

${ }^{14}$ Law Orders, Clay County Circuit Court, Clay, West Virginia, 1 April 1959.

${ }^{15}$ Clay County Historical Society, History of Clay County I, 46.

${ }^{16}$ J.G. Bradley, "Letter to Employees of Elk River Coal and Lumber Company," Clay Messenger, 2 December 1958.
} 
seniority and that when men are put back to work, it will be done on the same basis." 17 But the company never called back most of the men laid off.

It did not take long for the UMWA to return to Widen once Bradley sold to Clinchfield. UMWA officials arrived in Widen on March 10, 1959, to explain their program to the miners. "We are here on a goodwill mission...to explain the advantages of the UMW's program to the Widen miners and point out all the advantages our program offers." Some of those advantages were a minimum wages scale for all union members, increased wages, improved working conditions, statutory old-age pensions, workmen's compensation, and security for miner's families. But the UMWA made clear that it was not in Widen to "pressure anyone." The miners' contract with the League of Widen Miners was set to expire at the end of March, and James B. Farley, a UMWA representative, hoped "to have something worked out with the boys at Widen before their contract expires on March 31."18

By mid-March it looked like another unionization struggle would begin again in Widen. An article in the Charleston Daily Mail declared that the League of Widen Miners would resist unionization under the UMWA at Widen. A leaflet circulated around the workplace declared: "Those of you who have believed that the League is defeated before we have started may be happy to learn that we have just begun to fight!" A miner stated that he hung one such leaflet up in the washhouse and the company tore it down. The League members affirmed that scare tactics on the part of Clinchfield would not influence them to bring the UMWA to Widen. They upheld the right to chose their own representation and reminded the company that although it may want UMWA representation, it would also respect the wishes of its employees. ${ }^{19}$

Despite the stand taken by League of Widen Miners, the UMWA reported that by April 3, ninety percent of the workers at Widen had signed a pledge to join the UMWA and on April 7, Clinchfield signed a contract with the UMWA. Since 246 of 278 workers had signed to join the UMWA, no NLRB election was necessary to certify it as Widen miners' bargaining agent. The new UMWA contract gave Widen miners the current soft

\footnotetext{
17 “Cutback Idles 280 at Elk River Coal \& Lumber Co,” Clay County Free Press, 8 January 1959.

18 "UMW Officials Here Explaining Their Program to Widen Miners," Clay County Free Press, 12 March 1959.

19 “Mine Union Aims at Widen Control," Charleston Daily Mail, 2 April 1959.
} 
coal wages and made them eligible for membership in the union's welfare and retirement program..$^{20}$

After Clinchfield bought the mines at Widen the town began to disintegrate. The Bank of Widen and Widen High School closed, along with many other public buildings. Clinchfield cut off pensions to ELRICO retired miners that had been receiving payments of $\$ 100.00$ a month. Finally, the mines in Widen closed on December 31, 1963, and the two hundred men still working in the Rich Run mine were left unemployed. Clinchfield gave several reasons for the closing of the mine. It cited that the quality of the coal was unsuitable, the declining value of coal on the market was beginning to take its toll on the company, the equipment in Widen was dilapidated, and it cost the company too much for the upkeep of the tipple and other facilities. ${ }^{21}$

With no coal to transport from the town, the Buffalo Creek and Gauley Railroad ran its last train from Widen to Dundon on December 30, 1963. The successful railroad had operated in the black since 1959 and despite the closing of the Widen mine, continued to haul timber for Georgia-Pacific out of Swandale until 1965. After that year, the cars and engines of the $B C \& G$ were either left on the tracks to rust, deployed to other railroad lines, or were put on display in museums and amusement parks. ${ }^{22}$

Several instances after the 1963 closing gave hope for the future of Widen mines. The Clay County Free Press reported in 1979 that Majestic Mining would expand its operations to Widen and employ around 450 men. The projected operations, which seemed promising, included "two deep mines, a preparation plant, some surface mining and an extended rail line up into the Lilly Fork area." The future operations promised to provide over twenty-five years of employment for Clay County citizens and $\$ 3.5$ million dollars in taxes to the county. The company hoped to meet with Clay County planning officials to discuss projects for the surface mined areas, such as new housing for the area. ${ }^{23}$ Although reports of mine operations and employment opportunities flourished for

20 "UMW Claims Widen Mine 90 Pct. Won,” Charleston Daily Mail, 3 April 1959; "Widen Mine Signs UMW Contract; Was Last of Big Non Union Mines," Clay County Free Press, 9 April 1959.

${ }^{21}$ Wild Wonderful Widen. 8.

${ }^{22}$ Ibid, 8; Warden, 7. One engine from the Buffalo Creek \& Gauley railroad is located at Cass, West Virginia. The engine was in service for several years on the Cass Scenic Railroad, but is now out of service and only on display. Another engine from the $B C \& G$ has been used in service pulling a touring train in Dollywood in Pigeon Forge, Tennessee.

23 "Pittston Plans to Open Mines," Clay County Free Press, 3 January 1979. 
decades following the closing of the mines, none followed through to fruition. Majestic did mine coal in Widen for approximately a decade, between 1978 and 1988. Although there were and still are small coal mines working on the land around Widen, none of them have equaled the operations conducted in the area by the Elk River Coal and Lumber Company.

In 1989, Cowaco, Incorporated went into operations to reprocess two hundred acres of "gob pile" in Widen in order to sell the remaining coal. Gob piles were the huge mounds of unused coal that had amassed on ELRICO property during mining operations that still existed in 1989, smoldering on the outskirts of Widen. The company invested $\$ 5$ million dollars, hoping the piles contained enough coal deposits for profit. $^{24}$

Almost ten years after Cowaco reprocessed two of the large gob piles in Widen, the West Virginia Division of Environmental Protection began reclaiming seventy-seven acres of mine sites around Widen. DEP construction administrator, Eric Coberly, announced that the coal refuse overhangs and twenty-two acre waste impoundment pond were very dangerous and an "easy place for people to get killed." The DEP began the project in 1996 by extinguishing smoldering gob piles that had reached 190 feet high. Once the coal refuse cooled, the reclamation contractor covered it with a six-inch layer of soil capable of supporting vegetation. The DEP's next task was to drain 1.5 million gallons of waste water from the impoundment pond, raise the water's $\mathrm{pH}$ level above the existing acidic level of 4 , and release it down Taylor Creek. Final reclamation involved creating new channels for drainage down the man-made hillsides. ${ }^{25}$

The population of Widen has steadily fallen since the 1960s. The Y.M.C.A., African-American church, and several houses in town were dismantled and removed. Unused facilities were subject to vandalism and neglect. The water system had to be shut off, and in 1973, the elementary school was moved to the nearby town of Dille. ${ }^{26}$ By 1978, the population of Widen stood at 260. Thirty-five percent of the population was over the age of sixty and forty-five percent of the population was under the age of twenty. Unemployment for men had reached fifty-five percent. Nearly all of the men who were employed were coal miners. One-third worked in Widen for the new operator, Majestic

\footnotetext{
${ }^{24}$ Skip Johnson, "Widen Gob Piles May Yield Greenbacks," Charleston Gazette, 14 August 1987.

${ }^{25}$ Steve Myers, "Trying to Turn Back the Clock," Charleston Daily Mail, 8 January 1998.

${ }^{26}$ Wild Wonderful Widen, 9.
} 
Mining Company, while the others worked in nearby mines. The post office, church, and union hall were the only services still provided to the citizens of Widen. ${ }^{27}$

At the height of its production, the Elk River Coal and Lumber Company employed over seven hundred men and had a payroll of almost four million dollars. At its height, the town of Widen supported a population of three thousand, but only about two hundred people live in Widen today. ${ }^{28}$ The post office and Baptist church are the only two local institutions still providing public services to the citizens of Widen. When the Elk River Coal and Lumber Company moved out of Widen, it was only the preclude of the decline of the coal industry in the entire county.

In his 1947 report, Admiral Boone sited four major reasons for the decline of the coal industry as a whole in the United States. First, the seasonal nature of the industry resulted in a fluctuation in production. Secondly, the rise of oil and gas as fuels lowered the demand for coal. Thirdly, improvements in fuel efficiency also decreased the demand for coal. Finally, Boone sited the mechanization of the coal mining process as a reason for the decline of the coal industry. ${ }^{29}$

Scholars have also attributed the rise of the United Mine Workers of America as a cause for the decline of the coal industry. Howard Lee attributes John L. Lewis' strike tactics and yearly wage hikes as a factor in the downfall of the industry. Higher wages and more benefits on a yearly basis only influenced coal operators replace miners with machines that did not require benefits and wage increases. As a result, young miners were forced to move to growing industrial cities, outside the state, to find jobs in factories. By the end of the twentieth century, economic hardships continued the migration out of West Virginia as the state lost eight percent of its population between 1980 and $1990 .^{30}$

A multitude of factors forced the decline of the coal industry and specifically Clay County, leaving Widen's citizens to find new means of employment. Some have stayed in the county, where the largest employer is the Clay County Board of Education. Others

${ }^{27}$ Ibid, 9.

${ }^{28}$ Thompson, 19.

${ }^{29}$ U.S. Coal Mine Administration, xvi.

${ }^{30}$ Howard B. Lee, Bloodletting in Appalachia (Morgantown: McClain Printing Company, 1969), 172-180; Otis K. Rice and Stephen W. Brown, West Virginia: A History, $2^{\text {nd }}$ Ed. (Lexington: University Press of Kentucky, 1993), 288. 
have had no choice but to move out of the county for employment. Clay County supports one of the smallest populations in the state and only seven counties have a larger unemployment rate. Ninety-eight percent of those employed in Clay County commute to work, with an average travel time of forty-five minutes, usually out of the county. With no prospective economic development in the near future, the outlook continues to remain bleak for residents of Widen and Clay County. ${ }^{31}$

31 "Profile of Selected Economic Characteristics: 2000," "Employment Status and Commuting to Work: 2000," [On-line Databases], (U.S. Census Bureau, accessed November 20, 2002); available from http://factfinder.census.gov/; Internet. 


\section{Conclusion}

The Rich Run mine at Widen was just one of the many non-union operations John L. Lewis attempted to unionize during the 1950s. His harsh organizing campaigns were filled with violence and destruction of property in attempts to bring the philosophy of the United Mine Workers of America to non-union coal miners. After his cooperative agreements with the Bituminous Coal Operators Association in the late 1940s, Lewis initiated his drive to destroy non-union coal companies. He began with subtle discriminatory acts and eventually moved to an outright war with small coal companies. First, the UMWA made small union operators stick to their payments of royalties or even raised their fees, while large companies, mostly members of the BCOA, paid only partial royalties. Lewis also started a campaign to boycott small coal operators in 1958, but the National Labor Relations Board declared the move illegal. Nevertheless, the combined efforts of the UMWA and BCOA continued to exterminate small operators in the coal industry. ${ }^{1}$ Lewis' Darwinian plan to drive out the small companies operating under "obsolete and un-American, cheap labor conditions" was working. ${ }^{2}$ In 1950, small operators mined 20.7 percent of coal produced in the United States. By 1970, small operators had dwindled to only 7.3 percent of coal production. ${ }^{3}$ Widen was one such casualty of that war.

In 1960, John L. Lewis retired as president of the United Mine Workers of America. Mechanization, rising unemployment, declining safety conditions and disappearing benefits and pensions became frequent problems for the coal industry in the 1960s and 1970s. Wildcat strikes continued as miners sought to achieve their "living wage." A new group, Miners for Democracy, began a campaign to focus the UMWA back on the rank-and-file members. Its focal point was the Miners Bill of Rights. With safety as the main issue, Miners for Democracy stood for black lung benefits and reform of the Welfare and Retirement Fund. The group caused much commotion in the UMWA, and finally elected a President, Arnold Miller, who in 1972, began a program of reform in

\footnotetext{
${ }^{1}$ Seltzer, 73-75.

${ }^{2}$ Lewis, 112.

${ }^{3}$ Seltzer, 77-8.
} 
the UMWA. But even a vast reform of the UMWA could not arrest the declining unemployment in the ailing coal industry. ${ }^{4}$

In 1971 the United States Supreme Court ruled the cooperation between the UMWA and BCOA during the 1940s and 1950s to stabilize the coal industry as unconstitutional. The court believed the two organizations had "engaged in an unlawful conspiracy to eliminate and suppress competition and production in the coal industry and to control the Southern Appalachian and Southeastern Tennessee coal fields." But the ruling came too late to help the struggling miners who remained in the coal industry. Despite the rising unemployment, the coal industry was thriving largely due to the implementation of surface mining, a technique that involves the mass removal of coal and requires fewer miners. BCOA mines and UMWA miners suffered as more non-union mines benefited from the new mining techniques. By 1980, only forty-four percent of coal mined in the United States was mined by BCOA mines, compared to seventy-seven percent in $1970 .^{5}$

Miners have seen dramatic changes in their industry over the past century. The implementation of machines altered the miners' workplace and caused widespread unemployment. Miners have been fighting to save their jobs ever since. Now, machines are being supplemented with high explosives that tear the tops off mountains to extract coal. Only the future can tell what is in store for the coal industry, but it is safe to say that miners will continue to face the same declining employment they have for the past fifty years that has caused widespread poverty in Appalachia. With no other industries to absorb the redundant miners, many struggle to survive, and only dream of living the American standard John L. Lewis hoped to provide for miners so many years ago.

Joseph Gardner Bradley died on March 16, 1971, in Needham, Massachusetts. It is hard to keep from wondering what he would think about Widen today. He provided for these families for nearly fifty years, investing much money, and what would seem interest in the families of his town in Clay County. It is difficult to believe he would not be affected to see his once booming coal town as the poverty stricken hamlet of today. On the other hand, it is hard to believe that he ever had sincere feelings for his workers in

\footnotetext{
${ }^{4}$ Ibid, 108-131.

${ }^{5}$ Ibid, 78-9, 126.
} 
Widen. Bradley clearly provided for the residents of his town in order to keep them content with life in Widen, and for nearly fifty years he succeeded. His attempts to provide all things for his miners resulted in their being faithful, unquestioning servants for half a century. When the cost of providing for his employees became more than the profits those employees generated for him, however, he left. The absence of the domineering, yet benevolent provider, coinciding with the restructuring of the coal mining industry, resulted in the demise of the mines, the miners, and the community of Widen.

The strike of 1952-53 was the climax in the story of Widen. The fifteen months of turmoil that split the town ended up being the last stand for the architect of Widen. The toll of the strike on Bradley left him in debt and forced him to sell the company he and his family had built from the ground up. After Bradley sold out, he saw the decades of struggle against the United Mine Workers of America become null and void as the new owners of Rich Run mine signed a contract with the national union. Yet, it seems that Bradley anticipated the end of Widen, and being the businessman he was, knew it was time for him to get out despite his hatred of the UMWA. The departure of Bradley marked the end of the one of the largest non-union coal empires in the nation, and the town would never see the glory of its coal days again. 


\section{Bibliography}

\section{Primary Sources}

\section{Newspapers}

Charleston Daily Mail. Charleston, West Virginia. 1952-1998

Charleston Gazette. Charleston, West Virginia. 1952-1987

Clay County Free Press. Clay, West Virginia. 1952-1979

Clay County Messenger. Clay, West Virginia. 1945-1958

Widen News. Widen, West Virginia. 1952-1954.

\section{West Virginia State Archives Manuscript Collection}

Buffalo Creek and Gauley Railroad. Annual Report to Public Service Commission of the State of West Virginia. 1925-1948.

Buffalo Creek and Gauley Railroad. Financial Statements. 1910-1932.

Elk River Coal and Lumber Company. Financial Statements. 1911-1920.

\section{Government Reports}

Legislative History of the Labor Management Relations Act, 1947. Printed for the Subcommittee on Labor of the Committee on Labor and Public Welfare, United States Senate. Washington D.C.: U.S. Government Printing Office, 1974.

United States Bureau of the Census. Census of the United States: Population.

Washington, D.C.: United States Department of Commerce, Bureau of the Census, 1920-1960.

-----. "Profile of Selected Economic Characteristics: 2000." [On-line Database]. Accessed November 20, 2002; available from http://factfinder.census.gov/; Internet.

-----. "Employment Status and Commuting to Work: 2000." [On-line Database]. Accessed November 20, 2002; available from http://factfinder.census.gov/; Internet.

United States Coal Mine Administration. Medical Survey of the Bituminous Coal Industry: Report of the Coal Mine Administration. Washington, D.C.: United States Government Printing Office, 1947.

West Virginia Department of Mines and Mining. Annual Reports. Charleston: Department of Mines and Mining, 1905-1960. 
West Virginia Legislature. Governor's Investigating Committee. Charleston, 1953.

"Report and Proceedings of Widen Strike Committee." Appears in West Virginia Legislature, House of Delegates Journal, Appendix, 2 March 1953.

\section{Clay County Courthouse}

Law Orders. Clay County Circuit Court. Clay County Courthouse. Clay, West Virginia. 1952.

\section{Pamphlets}

Bradley, J.G. The Coal Operator and the Coal Miner-A Partnership. Address before West Virginia Mining Institute. Huntington, WV. 5 December 1922.

\section{Books}

\section{Secondary Sources}

Brophy, John. A Miner's Life. Madison: University of Wisconsin Press, 1964.

Clark, Walter E., ed. West Virginia Today. New Orleans: West Virginia Editors Association, 1941.

Clay County Historical Society. History of Clay County Volumes I and II. Clay: Clay County History Book Committee, 1989.

Corbin, David Alan. Life, Work, and Rebellion in the Coal Fields: The Southern West Virginia Miners, 1880-1922. Urbana: University of Illinois Press, 1981.

Dix, Keith. What's a Coal Miner to Do? The Mechanization of Coal Mining. Pittsburgh: University of Pittsburgh Press, 1988.

Dubofsky, Melvyn and Warren Van Tine. John L. Lewis: A Biography. New York: Quadrangle/The New York Times Book Company, Incorporated, 1977.

Eller, Ronald D. Miners, Millhands, and Mountaineers: Industrialization of the Appalachian South, 1880-1930. Knoxville: University of Tennessee, 1982.

Erikson, Kai T. Everything In Its Path: Destruction of Community in the Buffalo Creek Flood. New York: Simon \& Schuster, 1976.

Fulmer, William E. Union Organizing: Management and Labor Conflict. New York: Praeger Publishers, 1982

Goodrich, Carter. The Miner's Freedom. New York: Arno Press, 1925.

Gould, William B. A Primer on American Labor Law, $2^{\text {nd }}$ ed. Cambridge \& London: MIT Press, 1986. 
Hinrichs, A.F. United Mine Workers of America and Non-Union Coal Fields. New York: AMS Press, 1968.

Hume, Brit. Death and the Mines: Rebellion and Murder in the United Mine Workers. New York: Grossman Publishers, 1971.

Kirk, John W., compiler. Progressive West Virginians. Wheeling: The Wheeling Intelligencer, 1923.

Lane, Winthrop. Civil War in West Virginia: A Story of Industrial Conflict in the Coal Mines. Salem: Ayer Publishers, Incorporated, 1921.

Lee, Howard B. Bloodletting in Appalachia. Morgantown: McClain Printing Company, 1969.

Lewis, John L. The Miner's Fight for American Standards. Indianapolis: The Bell Publishing Company, 1925.

Lockard, Duane. Coal: A Memoir and Critique. Charlottesville: University of Virginia Press, 1998.

Millis, Harry A. and Emily Clark Brown. From the Wagner Act to Taft-Hartley: A Study of National Labor Policy and Labor Relations. Chicago: University of Chicago Press, 1950.

Morris, Homer Lawrence. The Plight of the Bituminous Coal Miner. Philadelphia: University of Pennsylvania Press, 1934.

Rice, Otis K. and Stephen W. Brown. West Virginia: A History. $2^{\text {nd }}$ ed. Lexington: University Press of Kentucky, 1993.

Seltzer, Curtis. Fire in the Hole: Miner and Managers in the American Coal Industry. Lexington: University of Kentucky Press, 1985.

Shifflett, Crandall A. Coal Towns: Life, Work, and Culture in Company Towns of Southern Appalachia, 1880-1960. Knoxville: University of Tennessee Press, 1991.

Steel, Edward M. Jr., editor. The Court-Martial of Mother Jones. Lexington: University Press of Kentucky, 1995.

Tams, W.P. The Smokeless Coal Fields of West Virginia: A Brief History. Morgantown: West Virginia University Libraries, 1963.

Trotter, Joe William, Jr. Coal, Class, and Color: Blacks in Southern West Virginia 19151932. Urbana: University of Illinois Press, 1990. 
Warden, William E. Buffalo Creek \& Gauley. Highland Hills: Ed Crist, Incorporated, 1991.

Wild Wonderful Widen, West Virginia: A Community Report. Widen: Institute of Cultural Affairs, 1980.

\section{Dissertations}

Lawrence, Randall Gene. "Appalachian Metamorphosis: Industrializing Society on the Central Appalachian Plateau, 1860-1913.” Ph.D. diss., Duke University, 1983.

Simon, Richard Mark. "The Development of Underdevelopment: The Coal Industry and Its Effect on the West Virginia Economy, 1880-1930." Ph. D. diss., University of

Pittsburgh, 1978.

\section{Articles}

“A Battle John L. Lewis Lost.” U.S. News and World Report. 29 January 1954, from Goldenseal 3, no. 1 (January-March 1977): 11-12.

Blizzard, William C. “There's Never Peace in West Virginia's Hills.” The Nation 177 (December 19, 1953): 548-549.

Cantrell, Betty, Grace Phillips, and Helen Reed. "Widen, The Town J.G. Bradley Built." Goldenseal 3, no. 1 (January-March 1977): 2-6.

Fishback, Price V. "Did Coal Miners 'Owe Their Souls to the Company Store'? Theory and Evidence from the Early 1900s." Journal of Economic History 46, no. 4 (December 1986): 1011-1029.

----- and Dieter Lauszus. "The Quality of Services in Company Towns: Sanitation in the Coal Towns During the 1920s." Journal of Economic History 49, no. 1 (March 1989): 125-144.

Thompson, Craig. "The Reign of Terror in Widen, W.Va." Saturday Evening Post. 20 February 1954.

Yeager, Barbara. "Mostly Work: Making a Home in Widen." Goldenseal 3, no.1 (January-March 1977): 7-10.

\section{Pamphlets}

Hickory and Lady Slippers: Life and Legend of Clay County People. Bicentennial ed. Clay: Clay County High School, 1977.

"Widen: An Appalachian Empire." Hickory and Lady Slippers: Life and Legend of Clay County People IV. Clay: Clay County High School, 1979. 
"Widen News Pictorial." Hickory and Lady Slippers: Life and Legend of Clay County People IV (Supplement). Clay: Clay County High School, 1979.

\section{Interviews}

Facemire, Billy G. Interview by author, 17 March 2001, Dille, West Virginia.

\section{Websites}

Given, Lola B. "Memories of Widen \& Dille, W.Va." [On-line Document]. July 1997, accessed September 25, 2000; available from http://www.rootsweb.com/ wvclay/claywd.htm; Internet. 


\section{Appendix: \\ Going Back Home to Widen}

Once the mines closed in Widen in 1963, the town rapidly deteriorated. Many visitors came back to the town to find it in a dilapidated state. The following is an excerpt from an article in Goldenseal. The reminiscence is by Virginia Chapman who wrote her thoughts regarding a visit back to Widen in 1968.

Today I went to Widen. Thomas Wolfe was right, 'You can't go home again.' If Widen had been my hometown, I would have been terribly saddened at the sight. I was only an occasional visitor at my brother's home in Widen when I was young. But the first sight left me with a nostalgic feeling. I couldn't find the house until it was pointed out to me. The tipple has been disassembled, some of it sold for scrap metal, and the rest lies I disarray on the hillsides. The buildings around the main opening are falling down. The huge, high building with its tin sides and broken windows stands guard over the empty splay pools, boiler room, washhouse, and Legion Hall. The main office is boarded up, as is the clubhouse and many, many other houses.

Heavy equipment, such as four big heavy shovels and smaller welding trucks, all bearing the insignia ELRICO stood deserted, and seemingly where they were last used. A house with a plaque by the door reading 'The Parsonage of Widen' stands in a row of empty houses, facing a row of dilapidated houses where once the elite of Widen lived. The bosses that helped run the operations lived in these houses with steam heat, indoor plumbing, and garages out back.

The streets are still black dirt, but the creek is a clear as any mountain stream.

The school is now only two rooms.... Part of the big school building is in the process of being torn town on orders of the State Fire Marshall.

Behind the school stands the new church, opened in 1954. Clean, gray stuccoed walls, trimmed in gleaming white, it stands almost three dimensionally against the hill behind, a fitting monument to the golden age of Widen. Inside the spacious chapel room, the emptiness was enhanced by the register stating the attendance that last two Sundays was 40 and 42. 
The building which was once a gym, but later the company store, is boarded up and the front is falling in. The old church is now the deserted U.M.W.A. Hall and stands opposite the seldom used huge community building. The swimming pool, tennis court, and lodge at the end of an impassible road are also in such disrepair that they could never be used again.

The water meter man said he serviced 75 meters, but some of these people live other places and still maintain their home in Widen. Most of the houses have different paint now, other than the Widen red of earlier times; and one house even has white aluminum siding which glistened glaringly in the sun. This alone would have been impossible when the mines were operating.

There isn't a black or foreign person left in the town. The old Negro church is still perched on the side of the hill overlooking the empty houses in 'colored town.'

There is still talk of opening the mine, but the feeling in Widen is that the opening would be in the Dundon-Harrison area and never again in Widen. Standing almost anywhere in Widen, one can look and see the results of strip mining in the surrounding hills. 16,500 trees were set out last year as part of the reclamation work, but it will be many years before they can cover up the ugliness. ${ }^{1}$

Ms. Chapman's account of her visit to Widen in 1968 vividly describes the state of the town immediately after the closing of the mines. Yet, it has continued to deteriorate even more over the past thirty years. After decades without means of employment or a paternalistic provider, Widen hardly even resembles the decrepit town Chapman described in 1968.

\footnotetext{
${ }^{1}$ Cantrell, et al, 5-6.
} 